Universidade de SÃo P AULO

INSTITUTO DE FÍSICA

INSTITUTO DE QUÍMICA

INSTITUTO DE BIOCIÊNCIAS

FACULDADE DE EDUCAÇÃO

\title{
Análise do princípio de Le Chatelier em livros didáticos de química
}

Renato Canzian

São Paulo

2011 


\section{Análise do princípio de Le Chatelier em livros didáticos de química}

Dissertação de mestrado apresentada ao Instituto de Física, ao Instituto de Química, Instituto de Biociências e a Faculdade de Educação da Universidade de São Paulo, para a obtenção do título de Mestre em Ensino de Ciências.

Área de Concentração: Ensino de Ciências

Orientador: Prof. Dr. Flavio Antonio Maximiano 
FICHA CATALOGRÁFICA

\section{Preparada pelo Serviço de Biblioteca e Informação do Instituto de Física da Universidade de São Paulo}

Canzian, Renato

Análise do princípio de Le Chatelier em livros didáticos de química. - São Paulo, 2011.

Dissertação (Mestrado) - Universidade de São Paulo. Faculdade de Educação, Instituto de Física, Instituto de Química e Instituto de Biociências

Orientador: Prof. Dr. Flavio Antonio Maximiano

Área de Concentração: Ensino de Química.

Unitermos: 1. Química (Estudo e Ensino);

2. Livro Didático; 3. Ensino e Aprendizagem. 


\section{AGRADECIMENTOS}

Primeiramente agradeço a Deus, aos meus pais, ao meu amigo Rafael e, em especial ao meu orientador, professor Flávio, que sempre me apoiou desde o início e trouxe muita luz para o desenvolvimento desde trabalho. A caminhada até este presente momento não foi fácil e agradeço pela infinita paciência na orientação deste trabalho pois, mesmo diante de tantas dificuldades, eu nunca me senti desamparado.

Agradeço também a todos os professores do Programa de Pós Graduação em Ensino de Ciências, em especial às professoras Dayse, Maria Eunice, e aos professores Paulo Porto e Marcelo Giordan, que deixaram sugestões relevantes para este trabalho durante o exame de qualificação.

À minha grande amiga lara pelas confidências durante todo o mestrado e a todos os colegas do nosso grupo de pesquisa. Lembrarei com carinho as nossas viagens ao ENEQ de Curitiba e de Brasília.

E, finalmente, agradeço a todos que de alguma maneira estiveram ao meu lado neste momento de crescimento profissional. 


\section{RESUMO}

CANZIAN, R., Análise do princípio de Le Chatelier em livros didáticos de química. 2011. 80 f. Dissertação (Mestrado). Instituto de Química, Instituto de Física, Instituto de Biociências e Faculdade de Educação, Universidade de São Paulo, São Paulo, 2011.

Este trabalho apresenta uma reflexão sobre o papel do princípio de Le Chatelier desde a sua criação e algumas implicações no ensino de química. Foram levantados aspectos históricos da evolução do princípio com o objetivo de discutir características como, por exemplo: o caráter universal do mesmo, problemas e limitações quanto à sua aplicação e possíveis alternativas ao uso do princípio. Também foram analisados como os livros didáticos de química no nível médio tratam muitos destes aspectos.

Além disto, é realizada uma discussão nestes textos didáticos a respeito das variáveis que influenciam no estado de equilîbrio tais como: concentração, pressão, catalisador e temperatura. Um aspecto presente na análise destas variáveis foi o levantamento de ilustrações presentes nos livros baseando-se nos níveis de representação presentes no triângulo de Johnstone.

Os principais resultados mostraram que os autores de livros de Química do Ensino Médio apresentam o conceito do princípio de Le Chatelier marcado por um caráter indutivo, vago, ambíguo, e sem apresentar uma fundamentação teórica e suas limitações, enfatizando-o como um princípio infalível ou uma verdade absoluta. Perpetuou-se no ensino de química, ao longo do tempo, a formulação mais simples e popular criada por Le Chatelier, no ano de 1888.

Outra conclusão importante refere-se ao fato de a maioria das figuras presentes nos livros didáticos estar relacionada ao nível macroscópico e a concentração é a alteração mais discutida. Poucas são as figuras que interligam os três vértices do triângulo. Resta ao professor o desafio de incluir as ilustrações faltantes, principalmente as microscópicas pois estas têm o objetivo de explicar aos estudantes o que ocorre do ponto de vista molecular quando se altera o estado de equilîbrio químico.

Portanto, este tratamento superficial do princípio pode favorecer processos de ensino-aprendizagem baseados na memorização, repetição e na sua utilização sem a compreensão exata dos fenômenos envolvidos.

Palavras-chave: livro didático, Princípio de Le Chatelier, equilíbrio químico, representações múltiplas no ensino de química. 


\section{ABSTRACT}

CANZIAN, R., Le Chatelier's Principle Analysis in chemical textbooks. 2011. $80 \mathrm{f}$. Dissertação (Mestrado). Instituto de Química, Instituto de Física, Instituto de Biociências e Faculdade de Educação, Universidade de São Paulo, São Paulo, 2011.

This work presents a reflection on the role of the Le Chatelier's principle concerned by its creation and some implications in the teaching of chemistry. The main purpose was to analyze as high school chemical textbooks approach with this subject. For this, historical aspects of the evolution of the principle were studied with the objective of discussing important characteristics, for example: the universal character of the principle, his problems and limitations regarding their applications to previse changes in chemical equilibrium systems and the possible alternatives to the use of the principle. It was found that the principle formulations were similar to that more simple and popular wrote by Le Chatelier, in the year of 1888. It was also made an analysis of how the textbooks address the issue of variables that influence in the state of equilibrium such as: concentration, pressure, catalyst and temperature. Also was analyzed the illustrations present in these books with the objective of address the equilibrium change based in the of Johnstone's triangle (that explicitly shows the macroscopic, microscopic and representational levels of chemical knowledge). The main results showed that the majority of the figures in textbooks refers only to macroscopic level and the effects done by of the equilibrium reactants concentration change. There are few figures which are related the three levels represented in the Johnstone's triangle. Is very important that teachers include the illustrations missing, mainly the microscopic level, once that this level is essential to correct understand of chemical equilibrium change in the molecular level. In general, the authors of chemical textbooks present the Le Chatelier's principle in an inductive manner, vague and ambiguous. They never present theoretical aspects and limitations in the application of the principle. This stresses the infallible character of Le Chatelier's principle and transmits the idea that it is an absolute truth. This superficial treatment of the principle can encourage processes of teaching-learning based on memorization and the students can correctly use the principle in the problems solutions without have an exact understanding the phenomena.

Keywords: textbook, Le Chatelier's Principle, chemical equilibrium, multiple representations in chemical education. 


\section{SUMÁRIO}

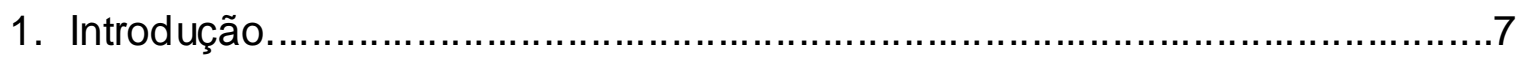

2. Aspectos históricos do princípio de Le Chatelier...............................................

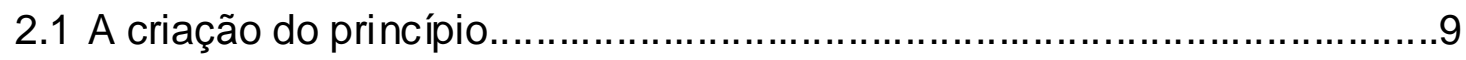

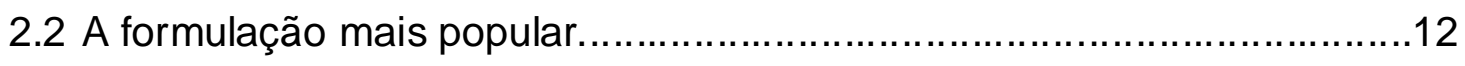

2.3 As últimas conclusões de Le Chatelier..............................................16

2.4 O princípio surge no ensino da química...............................................17

2.5 A popularização do princ ípio e seu caráter universal...............................19

3. Problemas e limitações quanto ao uso exclusivo do princípio de Le Chatelier

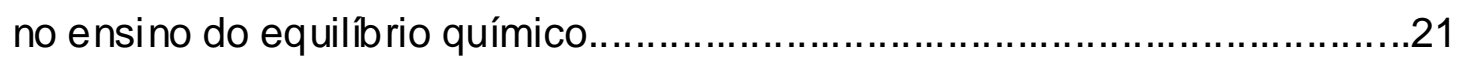

4. Alternativas ao uso do princípio de Le Chatelier........................................25

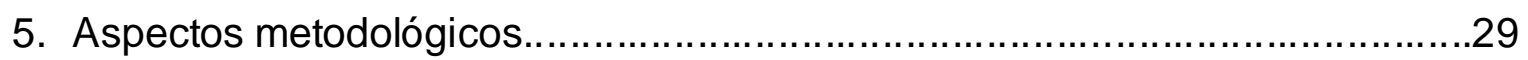

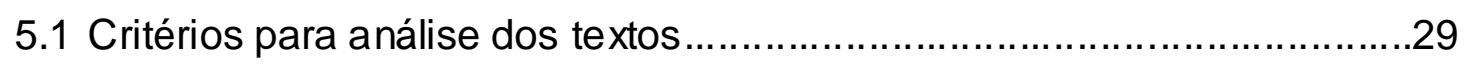

5.2 Critérios para análise de ilus trações....................................................31

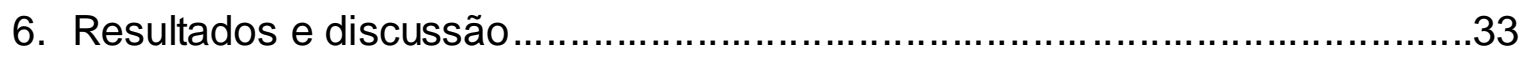

6.1 Como o princípio de Le Chatelier está formulado?..................................33

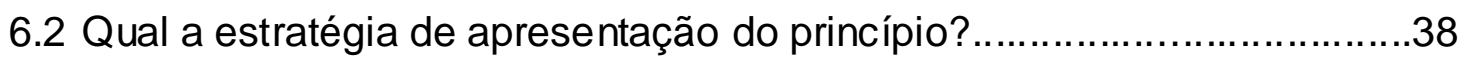

6.3 Quais variáveis se discutem nas mudanças de equilibrios

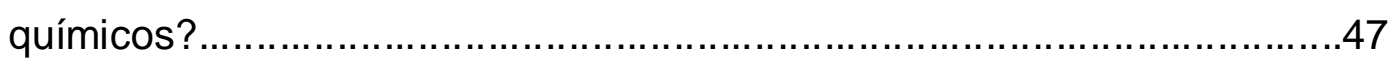

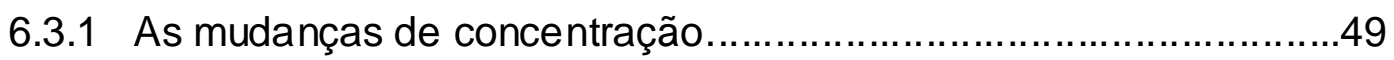

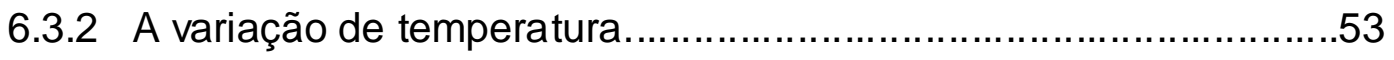

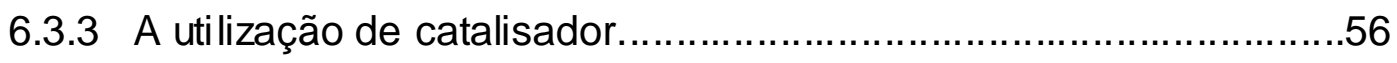

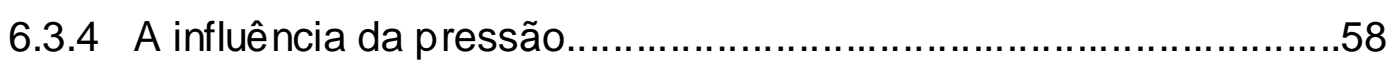

6.4 Considerações sobre a totalidade das ilustrações ...................................63

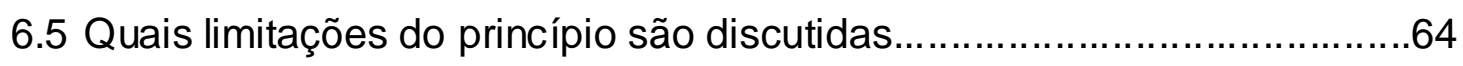

6.6 Quais são as alternativas ao princípio de Le Chatelier.............................67

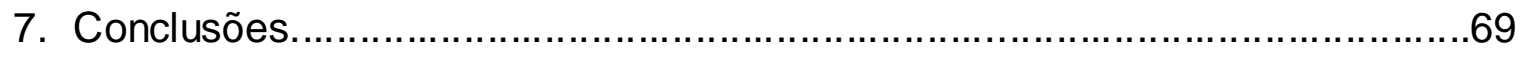

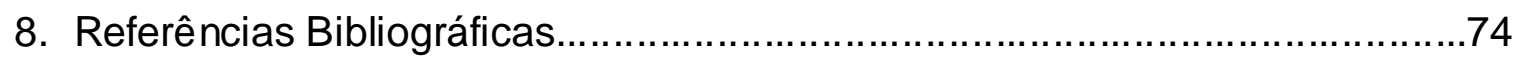

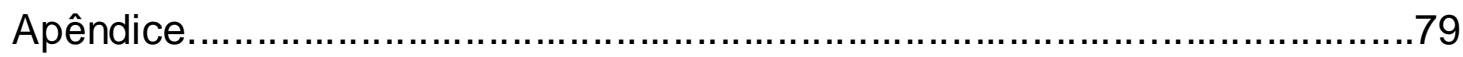




\section{INTRODUÇÃO}

O tema Equilibrio Químico é um dos assuntos mais importantes e difíceis no ensino da Química tanto no nível médio quanto no nível superior (WILSON, 1998). Trata-se de um tema de natureza abstrata que demanda o domínio de um grande número de conceitos subordinados (QUíLEZ-PARDO e SOLAZ-PORTOLES, 1995a) como, por exemplo, a clara compreensão de como as reações químicas ocorrem em nível molecular (MASKILL e CACHAPUZ, 1989).

É de se destacar, também, a importância deste tema para o estudo de outros aspectos da Química como o comportamento ácido-base, reações de oxirredução e de precipitação; sendo assim, faz-se necessário conhecer as dificuldades de aprendizagem e os erros conceituais relacionados bem como suas possíveis origens (QUÍLEZ-PARDO et al., 1993).

Vários trabalhos e revisões têm apontado várias dificuldades e erros conceituais relacionadas ao tema como: o problema das analogias utilizadas por professores e por livros didáticos (RAVIOLO e GARRITZ, 2008), as dificuldades relacionadas à resolução de problemas devido à falta de um correto controle das variáveis envolvidas, a adoção de estratégias didáticas incorretas, as dificuldades quanto à linguagem empregada (QUÍLEZ-PARDO, 1997a e 1997b), as dificuldades em compreender a natureza dinâmica do equilibrio químico, a incorreta aplicação do Princípio de Le Chatelier ou sua aplicação em situações que conduzam a previsões incorretas, as dificuldades em aplicar o Princípio de Le Chatelier em situações de mudança de temperatura e as dificuldades em considerar todos os fatores que afetam o estado de equilibrio (BARKER, 2001; RAVIOLO e MARTÍNEZ-AZNAR, 2003). Em virtude de todos os aspectos mencionados anteriormente, faz-se importante analisar como alguns destes itens são apresentados e discutidos em livros didáticos de química do Brasil.

Um dos aspectos mais relevantes do estudo de equilibrio químico é a consideração dos fatores relacionados com as alterações que pode sofrer um sistema em equilibrio, devido às mudanças das propriedades que o definem, geralmente referidas nos livros-textos como "deslocamentos do equilíbrio". Os Parâmetros Curriculares Nacionais (BRASIL, 2002) sugerem que os alunos devam ser capazes de identificar as variáveis que perturbam o estado de equilibrio químico 
e avaliar as consequências de se modificar a dinâmica do sistema em equilíbrio através de alterações nas propriedades dos mesmos.

Para atingir estes objetivos, o Princípio de Le Chatelier tem sido a principal ferramenta utilizada no ensino, pois, apresenta um papel fundamental na predição qualitativa da evolução de um sistema em equilíbrio a partir de alterações nas propriedades do mesmo.

Considerando que os livros didáticos são importantes instrumentos de homogeneização dos conceitos, conteúdos e metodologias educacionais, pretendese aqui analisar como os conceitos envolvidos nas alterações no estado de equilíbrio químico são apresentados em livros didáticos brasileiros de Química para o Ensino Médio. Além disto, o foco deste trabalho está particularmente centrado em analisar e refletir como o princípio de Le Chatelier é formulado e discutido nos livros didáticos, tendo em vista que este princípio é a principal ferramenta utilizada para a previsão de possíveis deslocamentos dos sistemas em equilíbrio (QUíLEZ-PARDO et al., 1993; QUÍLEZ e SOLAZ, 1995; QUÍLEZ 1997A).

Neste âmbito, procurou-se verificar algumas características na evolução histórica do princípio desde a sua criação, a estratégia de apresentação do princípio, os problemas e limitações de aplicação e as possíveis alternativas ao mesmo. Todos estes aspectos são amplamente discutidos assim como são também apresentadas suas implicações para o ensino da química.

Também foi feita uma análise criteriosa das diferentes variáveis que influenciam em sistema em equilíbrio químico modificado. São aqui discutidas implicações para as variáveis: concentração, temperatura, pressão e catalisador. $\mathrm{Na}$ discussão destas variáveis são utilizados como referencial teórico o triângulo de Johnstone no levantamento de figuras e gráficos. Neste aspecto, tem-se o objetivo de relacionar os universos macroscópico, microscópico e representacional nas ilustrações presentes nos livros didáticos.

Espera-se, assim, apresentar reflexões que possam auxiliar professores e autores de materiais didáticos no sentido de identificar problemas no processo de ensino-aprendizagem e elencar sugestões com o objetivo de promover um verdadeiro entendimento dos conceitos químicos por parte dos estudantes. 


\section{APONT AMENTOS HISTÓRICOS SOBRE O PRINCÍPIO DE LE CHATELIER}

\subsection{A criação do princípio}

Henry Lois Le Chatelier nasceu na França, em oito de outubro de 1850, e por influência de sua família direcionou seus estudos para a área científica, até formarse engenheiro químico e metalúrgico. Em 1877 tornou-se professor de Química na Escola de Minas de Paris e, posteriormente, começou a lecionar Química Inorgânica na Universidade de Paris, onde permaneceu até 1908. Este renomado cientista procurava mostrar a necessidade de relacionar a Química pura e aplicada na solução de problemas industriais. Tornou-se grande autoridade nas áreas de metalurgia, metalografia, cimentos, vidros, entre outras, tendo publicado mais de quinhentos artigos em periódicos e livros a respeito destes assuntos (OESPER, 1931). Porém, sem dúvida, sua mais importante contribuição para 0 desenvolvimento da Química, na virada dos séculos XIX a XX, foi justamente a formulação do princípio que leva o seu nome, o Princípio de Le Chatelier, que pretende predizer a evolução de um sistema em equilíbrio químico, quando o mesmo é submetido a uma alteração no valor de uma das propriedades físicas que o define.

O primeiro artigo referente ao Princípio de Le Chatelier foi publicado em 1884 e tem sido objeto de estudo de muitos autores no que diz respeito às dificuldades e erros conceituais relacionados à sua aplicação (QUÍLEZ-PARDO, 1995). Neste artigo, pode-se ler:

Todo sistema em equilíbrio químico estável submetido à influência de uma causa externa que tenda a fazer variar, seja sua temperatura, seja seu estado de condensação (pressão, concentração, número de moléculas numa unidade de volume) ${ }^{1}$, em sua totalidade ou somente em algumas de suas partes, experimenta apenas modificações internas, as quais, se ocorressem isoladamente, acarretariam modificação de temperatura ou de estado de condensação de sinal contrário àquela resultante da ação exterior. ${ }^{2}$ (LE CHATELIER, 1884). 
Esta primeira formulação foi elaborada de forma indutiva sem nenhuma justificativa teórica ou modelo explicativo. Para a formulação deste enunciado, Le Chatelier se apoiou nos trabalhos de outros pesquisadores, dentre os quais J.H. van't Hoff, que estudou a evolução de sistemas em equilibrio alterados por uma mudança de temperatura. Esta lei ficou conhecida como "princípio do equilíbrio móvel" e afirma: "uma diminuição de temperatura, a volume constante, desloca um equilíbrio químico para a formação do sistema que desenvolve calor" (QUÍLEZPARDO, 1995 e TREPTOW, 1980).

Além dos trabalhos de Van't Hoff, Le Chatelier também se baseou no trabalho de G. Lippmann. Este último propôs uma regra qualitativa relativamente simples que expressava a "reciprocidade" entre fenômenos elétricos. (a força eletromotriz se transforma de maneira reversível em força magnética, mecânica, etc.). Esta regra está expressa abaixo: "o sentido no qual ocorre um fenômeno é sempre tal que o fenômeno recíproco tende a se opor à produção do fenômeno primitivo". (QUíLEZPARDO, 1995)

Baseado na regra de Lippmann, Le Chatelier relacionou "processos químicos reversíveis" (que é ocaso do equilibrio químico) com "fenômenos elétricos reversíveis". Por sua vez, é importante ressaltar que Lippmann também se apoiou em outra regra qualitativa, formulada algumas décadas antes, o chamado princípio de Lenz, de 1833, cujo enunciado foi transcrito a seguir (SOLAZPORTOLES,1995b): "Quando uma força que atua sobre uma corrente elétrica primária induz uma corrente secundária, a direção desta produzirá uma ação eletrodinâmica no sentido oposto ao da força atuante".

\footnotetext{
1 É interessante notar que o termo "condensação", utilizado na formulação original do princípio, está empregado de maneira diferente daquela que utilizamos atualmente. No caso, Le Chatelier utiliza este termo tanto para expressar pressão como concentração.

2.Tradução nossa. O enunciado original em francês diz: "Tout système en equilibre chimique stable soumis à linfluence d'une cause extérieure quitend à faire varier soit sa température, soit sa condensation (pression, concentracion, nombrede molécules dans l'unité de volume) das sa totalité ou seulement dans qualques-unes de sesparties, ne peut éprouver que des modifications intérieures, qui, se elles se produisaient seules, amèneraient un changement de température ou de condensation de signe contraire à celui résultant de la cause extéuriere." (Le Chatelier, 1884). Para a tradução do enunciado em espanhol consultar: Quílez-Pardo e Solaz-Portoles, 1995b
} 
A grande contribuição de Le Chatelier foi generalizar estas ideias ampliandoas para os fatores envolvidos nas alterações impostas a um sistema em equilíbrio químico.

Assim, além da temperatura presente na regra de Van't Hoff, ele também considerou, no primeiro enunciado proposto, mudanças na condensação do sistema, ou seja, nas outras duas variáveis intensivas mais importantes no controle de uma reação química, a pressão e a concentração (QUíLEZ-PARDO, 1995).

Tem-se a impressão de que muitos cientistas do século XIX buscavam formular regras qualitativas simples e gerais, como apresentado nos princ ípios de Lenz, princípio do Equilíbrio Móvel de Van't Hoff, a regra de Lippmann e o princípio de Le Chatelier, este último formulado com base nos anteriores. Ao analisarmos todos estes princípios ou regras da época, chega-se à conclusão de que todos referem-se a um "determinado sistema" que, ao sofrer uma modificação em suas condições, vai reagir no sentido oposto ao fator que o está modificando. É de se perguntar se esta concepção não está impregnada da concepção Aristotélica de que a natureza tem o seu "lugar ou estado natural" e qualquer ação que promova uma modificação a esta "condição natural" provoque uma reação de sentido oposto que leve o sistema (natureza) de volta ao seu "estado natural" ou "ponto de equilíbrio".

Neste sentido, outro importante aspecto a ressaltar é o da ideia de que a natureza se opõe a qualquer modificação para manter as suas leis naturais. Esta visão é muito antiga e bem disseminada em nossa cultura, está presente, por exemplo, no pensamento dos importantes filósofos gregos Aristóteles e Teofrasto (GOLD E GOLD, 1984). Sob esta concepção da natureza é muito fácil compreender que a lei de deslocamento de equilíbrio de Le Chatelier receba o "status" de um princípio universal e adquira inclusive um caráter metafísico (DEVENTER, 1927 apud QUÍLEZ-PARDO e SANJOSÉ-LOPEZ, 1996b, GOLD E GOLD, 1984). Este caráter metafísico do princípio o fez se tornar extremamente popular devido à sua relação com inúmeros aspectos do cotidiano.

Não restam dúvidas de que o estabelecimento destas regras ou princípios qualitativos facilita, desde o ponto de vista prático quanto didático, à medida que generaliza e simplifica a evolução de sistemas físicos e químicos quando se altera alguma variável que define tais sistemas. Gold e Gold (1984) mencionam outras descobertas históricas anteriores à formulação de Le Chatelier além das citadas anteriormente e que podem ter tido influência sobre a sua criação por Le Chatelier. 
Dentre estas, se destacam: a Lei de Ação das Massas de Guldberg e Waage, de 1864, a equação de Clayperon formulada em 1834 e os estudos de J. Thomson sobre o efeito da pressão na temperatura de ebulição.

É importante salientar que o princípio de Le Chatelier também ficou conhecido nesta época, principalmente por autores alemães, como princípio de Le ChatelierBraun devido ao fato de que, em 1888, o químico alemão Ferdinand Braun estudou o efeito da pressão na solubilidade dos sais em água, relacionando as mudanças das variáveis aos sistemas termodinâmicos modificados. Porém, mesmo diante deste fato, a nomenclatura "princípio de Le Chatelier-Braun" acabou caindo em desuso e dificilmente aparece em estudos recentes. (GOLD e GOLD, 1984)

\subsection{A formulação mais popular}

Quatro anos mais tarde, em 1888, Le Chatelier apresenta uma segunda formulação do princípio, classificado pelo autor como uma lei puramente experimental. Esta lei, escrita de uma forma mais breve, simples e generalizada foi denominada como "lei de oposição da reação à ação". A descrição desta formulação encontra-se no livro Leçons sur le carbone ${ }^{2}$, la combustion et les lois chimiques, um manual didático publicado por Le Chatelier em 1908 (QUÍLEZ-PARDO, 1995).

Todo sistema em equilíbrio experimenta, devido à variação de apenas um dos fatores do equilibrio, uma variação em um sentido tal que, se ocorresse isoladamente, levaria a uma variação de sentido contrário ao fator considerado. (LE CHATELIER, 1888 apud QUíLEZPARDO,1995).

Neste novo trabalho, Le Chatelier apresenta uma análise para cada uma das diferentes propriedades de um sistema em equilíbrio (temperatura, força eletromotriz, pressão e concentração) apresentando um enunciado específico para cada caso. $O$ primeiro, referente à temperatura diz o seguinte:

\footnotetext{
${ }^{2}$ Tradução nossa. O enunciado original em francês diz: "Tout système en èquilibre chimique éprouve, du fait de la variation d'un seul des facteurs de l'équilibre, une transformation dans un sens tel que, si elle se produisait seule, elle amènerait une variation du signe contraire du facteur consideré.” (Le Chatelier, 1888 apud Quílez Pardo, 1995).
} 
Toda elevação de temperatura produz uma transformação sobre o sistema químico no sentido de uma absorção de calor que conduziria a uma diminuição de temperatura, se ocorresse isoladamente. (LE CHATELIER, 1888 apud QUÍLEZ-PARDO,1995)

Com relação à variação da força eletromotriz afirma:

Toda variação de força eletromotriz, produzida em um ponto de um sistema químico, provoca uma deformação no sistema, de modo que induz no ponto considerado, se ocorresse isoladamente, a uma variação de força eletromotriz de sinal contrário. (LE CHATELIER, 1888 apud QUílEEZ-PARDO,1995)

O terceiro fator considerado diz respeito à pressão: "o aumento da pressão de todo um sistema em equilíbrio ocasiona uma transformação que tende a diminuir a pressão”. (LE CHATELIER, 1888 apud QUÍLEZ-PARDO,1995)

Logo após esta longa descrição, Le Chatelier apresenta alguns exemplos mostrando variações da temperatura de fusão devido à compressão e ainda a alteração da condensação de vapores por aumento de pressão. Os exemplos apresentados fazem menção a diversos processos químicos, como a decomposição do pentacloreto de fósforo e do ácido carbônico.

Por fim, ele escreve o seguinte texto para as mudanças de condensação (definida por Le Chatelier como quantidade de matéria por unidade de volume):

A variação da condensação de um dos elementos ocorre no sentido tal que a adição de determinada quantidade deste elemento determina uma transformação que provoque uma diminuição de sua condensação". (LE CHATELIER, 1888 apud QUÍLEZ-PARDO,1995)

Para Le Chatelier este quarto caso possui inúmeras aplicações na química no estudo sobre as variações de massa. Seu estudo ilustra as experiências de esterificação de Berthelot e as de dissociação do ácido iodídrico de Lemoine. Os resultados mostraram que a adição de uma quantidade de uma substância ao equilîbrio químico provoca uma reação no sentido de diminuir a "condensação" desta substância. 
Além disto, ao mostrar outros casos particulares, ele reforça a importância da ação da massa como forma de melhorar o rendimento das reações químicas (QUÍLEZ-PARDO, 1995).

Neste amplo trabalho fica clara a relação que Le Chatelier estabelece com os fundamentos básicos da física clássica. Ele considerou que os sistemas químicos comportam-se de maneira semelhante aos sistemas mecânicos quando sofrem uma determinada perturbação, ou seja, ambos devem reagir para alcançar uma nova posição de equilíbrio estável. Desta forma, Le Chatelier concluiu que as reações químicas são governadas segundo os modelos da mecânica clássica, ao ponto de ele considerar a existência da chamada "mecânica química". Para caracterizar esta argumentação segue a versão traduzida de um trecho deste trabalho de Le Chatelier (LE CHATELIER, 1888 apud QUÍLEZ-PARDO E SOLAZ-PORTOLES, 1995B).

[...]esta lei geral de oposição à ação e da reação é simplesmente uma generalização da condição de estabilidade dos sistemas mecânicos. Esta condição bem conhecida supõe que ao aplicarmos uma força em um ponto de um sistema em equilíbrio é necessário que a deformação do sistema desenvolva uma força que tenda a produzir um deslocamento de sentido contrário, ou seja, uma força de sentido oposto àquela introduzida ao sistema, concluindo, desta forma, que a reação deve ser oposta à ação.

Neste intenso estudo ele retoma as idéias científicas muito difundidas na época ao se utilizar de analogias da física clássica para estudar os equilíbrios químicos. Somente no último capítulo deste trabalho, Le Chatelier apresenta algum tipo de justificativa teórica, porém apenas para estudo do efeito da temperatura. Ele menciona que para os efeitos de pressão e força eletromotriz os raciocínios seriam semelhantes, mas, não os apresenta e, por fim, não discute qualquer fundamentação teórica para o efeito da variação de massa. (QUÍLEZ-PARDO, 1995 e SOLAZ-PORTOLES, 1995b).

Sendo assim, mesmo apresentando inicialmente um enunciado mais simples e geral que aquele de 1884, Le Chatelier apresenta, neste novo trabalho, uma explicação mais detalhada dos conceitos relacionados ao princípio, ao discutir as 
formulações específicas para cada tipo de alteração imposta ao sistema em equilibrio.

Em 1908, Le Chatelier faz uma nova publicação do princípio formulado em 1888 no seu livro didático Leçons sur le carbone et lois chimiques, no capítulo dedicado às leis da mecânica química. Ele reapresenta uma revisão da lei de deslocamento de equilibrio pela variação da temperatura, pressão e força eletromotriz. Le Chatelier ressalta que os resultados obtidos de cada uma das formulações matemáticas dos três casos mencionados são provenientes de um enunciado geral e muito simples, sem a necessidade de se utilizar qualquer fórmula algébrica. O enunciado publicado assemelha-se à formulação de 1888, e está transcrito abaixo: (LE CHATELIER, 1926):

A modificação de algumas condições que podem influir sobre um estado de equilíbrio químico de um sistema, provoca uma reação em um sentido tal que tenda a produzir uma variação de sentido contrário à condição externa modificada.

E continua explicando:

Um aumento de temperatura provoca uma reação que tende a produzir um decréscimo de temperatura, ou seja, uma reação com absorção de calor. Um aumento da pressão produz uma reação que tende a produzir uma reação com diminuição de pressão, ou seja, provocando uma redução de volume.

E finalmente generaliza sua lei para variações de massa da seguinte maneira: "O aumento da massa em um sistema homogêneo de uma das substâncias em equilíbrio provoca uma reação que tende a diminuir a massa da mesma".

Assim, novamente Le Chatelier apresenta neste trabalho, após um enunciado geral, enunciados específicos para variações de temperatura, pressão e, de maneira paralela aos resultados anteriores, surge um aspecto novo em relação ao seu trabalho anterior, a generalização do princípio também para variações de massa (QUÍLEZ-PARDO e SOLAZ-PORTOLES, 1995). 
É interessante também citar que neste livro, Le Chatelier propõe um novo enfoque ao ensino da química, na medida em que enfatiza o estudo das leis ponderais e da então chamada mecânica química, isto é, uma abordagem que busca tratar os fenômenos químicos a partir das leis e princípios da Física Clássica, além de incluir diferentes aplicações industriais, que ele denominou de "a ciência industrial". (QUíLEZ-PARDO e SANJOSÉ-LOPEZ, 1996b).

\subsection{As últimas conclusões de Le Chatelier}

Finalmente, no ano de 1933, após receber algumas críticas e observações, Le Chatelier reconheceu que havia cometido um erro no enunciado da lei de deslocamento do equilibrio químico ao considerar que os aumentos da concentração e da massa eram sempre paralelos e, diante de várias críticas que até então se sucederam, afirma que o primeiro enunciado de 1884, que cita textualmente os fatores temperatura, pressão e concentração (na época denominada condensação), era exato enquanto que o segundo de 1888 era inexato. (QUíLEZ-PARDO, 1995). A publicação desta correção está transcrita a seguir:

Chamei a atenção que meus diferentes enunciados para a lei de deslocamento de equilibrio não são todos iguais como eu acreditava. Alguns são inexatos, e são estes que geralmente são adotados. $O$ erro cometido pelo enunciado da lei de deslocamento de equilibrio é a consideração de que o aumento da concentração e da massa são sempre paralelos [...] O primeiro enunciado que fiz em 1884 no Comptes Rendus é exato; Entretanto, o correspondente escrito em Annales des Mines em 1888 é inexato. $O$ enunciado correto é o seguinte: em uma mistura homogênea em equilibrio químico, 0 aumento da concentração de uma das substâncias que participam na reação provoca o deslocamento de equilíbrio em um sentido tal que a reação tenda a diminuir a concentração da substância adicionada.(SOLAZ-PORTOLES, 1995b) 
Esta importante conclusão implica que uma diminuição da concentração de uma substância não implica necessariamente em uma diminuição de sua massa, ou seja, esta diminuição pode ser provocada pelo aumento do volume do sistema. 0 raciocínio inverso também é válido: um aumento da concentração de uma substância não implica necessariamente em um aumento de sua massa, ou seja, este aumento pode ser provocado por uma redução no volume do sistema. Três anos após estas importantes considerações, em 1936, morre Henry Lois Le Chatelier.

\subsection{O princípio surge no ensino da química}

Um dos primeiros autores de livros-didáticos a formular o princípio de Le Chatelier foi Nernst em 1898, que o apresentou em seu livro chamado Tratado de Química Teórica (QUÍLEZ-PARDO e SANJOSÉ-LOPEZ, 1996b, QUÍLEZ-PARDO, 1995). Outro importante autor a mencionar o princípio no ensino da química foi Ostwald, no livro Eléments de chimie inorganique, de 1904 (OSTWALD, 1904 apud QUÍLEZ-PARDO e SANJOSÉ-LOPEZ, 1996b). Este foi um livro seminal que teve ampla divulgação e formatou o ensino de química da época. $O$ enunciado de Ostwald afirma:

Se um sistema em equilibrio é submetido a uma perturbação, por meio da qual o equilibrio seja perturbado, uma mudança ocorrerá, se possível, que anule parcialmente a alteração. (OSTWALD, 1904 apud QUÍLEZ-PARDO e SANJOSÉ-LOPEZ, 1996b)

Tanto esta formulação de Ostwald quanto a proposta por Nernst foram elaboradas com base no enunciado mais simples e geral presente no Leçons sur le carbone e equivalente também à formulação de 1888, que Le Chatelier reconheceria anos mais tarde ser inexata (QUíLEZ-PARDO, 1995). Estes dois autores foram os responsáveis pelo início da grande popularidade que o princípio ganharia ao longo do tempo entre os autores de livros de química. (QUíLEZ-PARDO e SANJOSÉLOPEZ, 1996b, QUÍLEZ-PARDO, 1995). 
Um aspecto interessante e inusitado que o enunciado de Ostwald trouxe em relação aos anteriores foi a introdução, em sua descrição, de um condicionante à possibilidade de ocorrer uma mudança no estado de um sistema em equilíbrio, a de que o "o equilíbrio seja perturbado" pela alteração aplicada. Assim, se uma alteração, como por exemplo, a adição de um gás inerte a um sistema em equilibrio gasoso a volume constante, não provocar nenhuma "perturbação" não há alteração do estado de equilibrio. Essa importante condição não aparecia nos enunciados propostos por Le Chatelier. De qualquer forma, o termo perturbação é bem amplo e vago, podendo-se questionar qual seria o seu exato significado. Outro aspecto interessante deste enunciado é que "[...] uma mudança ocorrerá, se possível, que anule parcialmente a alteração". Novamente, está presente a ideia dos fenômenos recíprocos. Analisando este aspecto, a condição "se possível" torna o enunciado ainda mais vago.

Ao olharmos somente para o enunciado do princípio cria-se a falsa sensação de que a primeira formulação é mais completa, o que não é verdade, pois Le Chatelier, após apresentar a segunda formulação simplificada, descreve detalhadamente as mudanças de temperatura, força eletromotriz, pressão e condensação. A grande questão, para os autores de livros didáticos atuais neste caso é que, ao apresentar esta segunda formulação mais simples (a de 1888), seria interessante que a mesma fosse seguida de uma explicação de como cada fator pode influir no estado de equilíbrio, assim como foi realizado no longo trabalho de Le Chatelier. No entanto, se apresentada apenas a formulação geral do princípio sem os exemplos, pode-se levar à crença de que o mesmo tem um caráter universal, ou seja, válido em qualquer situação. Pereira (1989) ressalta que alguns enunciados do princípio de Le Chatelier que estão escritos em alguns livros não fazem sentido, são ambíguos ou incorretos caso sejam analisados de maneira literal.

Na edição francesa de 1922, denominada Tratado de química geral, Nernst volta a destacar o princípio de Le Chatelier e apresenta um novo aspecto, a relação deste com o princípio da ação e reação da mecânica clássica. Neste caso, o autor não coloca a sua contribuição no enunciado do princípio, ou seja, ele publica simplesmente a cópia fiel da formulação mais simples e popular, de 1888. (QUíLEZPARDO E SANJOSÉ-LOPEZ, 1996b). 


\subsection{A popularização do princípio e seu caráter universal}

A aparente simplicidade do enunciado formulado em 1888 e suas variantes, e a falta de qualquer tratamento matemático baseado nos princípios da termodinâmica, tornaram o princípio popular e provocaram um grande impacto na Química do final do século XIX, devido à possibilidade de o princípio de Le Chatelier ser aplicado em numerosas situações dentre as quais importantes aplicações industriais, como a obtenção de ácido sulfúrico pelo método de contato e a síntese da amônia pelo processo Haber-Bosch (QUíLEZ-PARDO E SOLAZ-PORTOLES, 1995b).

Estas características também tornaram o princípio muito popular no ensino de Química, pois mesmo pessoas que não estejam familiarizadas com a linguagem matemática podem usufruir de uma regra simples e geral, que lhes permite fazer previsões e aplicá-la a diferentes situações ou sistemas (QUíLEZ-PARDO et al., 1993, QUÍLEZ-PARDO e SANJOSÉ-LOPEZ, 1996b, QUÍLEZ-PARDO, 1995).

Todas estas razões promoveram a universalização do princípio em diversas áreas do conhecimento como: economia, sociologia, biologia e psicologia entre outras (SANJOSÉ-LOPEZ, 1996b; QUÍLEZ, 1995). Sanden relaciona a validez geral do princípio com a primeira e segunda lei de Newton além de citar alguns fatos da vida cotidiana que demonstram a utilização do mesmo. Outros autores, como Steiner e Campbell chegam a afirmar que (SANJOSÉ-LOPEZ, 1996B):

O princípio possui aplicações mais amplas que qualquer outro presente na química pois pode ser aplicado tanto aos aspectos físicos e biológicos como também aos campos da economia e das relações humanas.

Quilez-Pardo (1995) conta que em um livro didático de química pode-se encontrar a seguinte observação:

Observe que este enunciado não limita o princípio de Le Chatelier aos sistemas químicos. Ele pode ser aplicado, com igual validez aos equil librios físicos, biológicos, econômicos e a outros equilíbrios. (Quílez-Pardo, 1995) 
De Heer (1957) menciona em seu estudo outros nomes interessantes que o princípio de Le Chatelier recebeu tais como: "princípio da habilidade de adaptação", "princípio de preservação de estado tanto quanto for possível". Neste trabalho, De Heer (1957) afirma que muitos estudiosos possuem a ideia errônea de que o princípio de Le Chatelier é verdadeiro no sentido que expressa um lei fundamental da natureza, cuja validez não pode ser questionada.

Mesmo autores mais recentes continuaram enfatizando o caráter universal do princípio. Bodner e Pardue (1989) apud SanJosé-Lopez (1996b), ao final do capítulo de equilíbrio químico, apresentam um exercício em que o princípio de Le Chatelier pode ser aplicado a diferentes campos do conhecimento como as demais ciências naturais além de outras áreas como a psicologia, economia e ciências políticas. Um autor de livro de física (SIVOUKHINE apud SANJOSÉ-LOPEZ, 1996b) conclui que o princípio de Le Chatelier, na verdade, é um princípio geral da física pois é capaz de interpretar o movimento giroscópico. E para finalizar, Lewis apud Quílez-Pardo (1995) afirma que o princípio é uma generalização de conseqüências experimentais, e que possui aplicação em todas as áreas da física e da química.

Max Planck é um dos primeiros autores a criticar esta visão metafísica do princípio no que diz respeito às possíveis mudanças decorrentes na natureza, Segundo Planck (apud DE HEER, 1957):

\footnotetext{
A ideia de que a natureza certamente está interessada em preservar o estado de equilibrio a qualquer custo é errada. A natureza é indiferente, ora pode reagir de uma maneira e, em outros casos, reagir de maneira contrária.
} 


\section{PROBLEMAS E LIMITAÇÕES QUANTO AO USO EXCLUSIVO DO PRINCÍPIO DE LE CHATELIER NO ENSINO DO EQUILÍBRIO QUÍMICO}

Vários trabalhos têm discutido as limitações do emprego do Princípio de Le Chatelier enfatizando que muitos cientistas possuem a idéia errônea de que o princípio de Le Chatelier é "verdadeiro" no sentido de expressar uma "lei fundamental da natureza", cuja validade não poderia ser questionada (DE HEER, 1957, TREPTOW, 1980 e QUÍLEZ-PARDO e SANJOSÉ-LOPEZ, 1995).

A primeira crítica contundente ao princípio de Le Chatelier surgiu quatro anos após a primeira formulação, em 1888. O estudo do químico alemão Ferdinand Braun sobre o efeito da pressão na solubilidade dos sais em água, já mencionado anteriormente, apresenta uma justificativa teórica formal em seu estudo, (aceita por vários anos) enquanto Le Chatelier não apresenta qualquer justificativa de caráter teórico, pois o mesmo apenas se baseou na indução, semelhança entre fenômenos e generalização dos casos estudados. É o próprio Le Chatelier que define o seu princípio como sendo "puramente experimental". Além disto, Braun torna contundente a crítica a Le Chatelier por este não definir os limites de aplicação de seu princípio (GOLD E GOLD, 1984).

Particularmente referindo-se ao emprego deste princípio no âmbito educacional, especificamente no Ensino Médio, alguns estudos da década de 1990 continuaram abordando outras situações em que o mesmo se encontra limitado podendo gerar, nestes casos, erros conceituais significativos. Alguns destes exemplos aparecem na adição de sólidos e na variação de pressão do sistema, ambos em equilîbrios heterogêneos; e na adição de um gás inerte a um equilîbrio homogêneo gasoso (QUÍLEZ-PARDO e SANJOSÉ-LOPEZ, 1995).

No caso da adição de um reagente sólido em um equilíbrio heterogêneo, como no exemplo da decomposição de um sólido (cloreto de amônio) em dois produtos gasosos $\left(\mathrm{NH}_{4} \mathrm{Cl}_{(\mathrm{s})} \rightleftarrows \mathrm{NH}_{3(\mathrm{~g})}+\mathrm{HCl}_{(\mathrm{g})}\right)$ ou do equilíbrio de solubilidade de um sólido iônico $\left(\mathrm{AgCl}_{(\mathrm{s})} \rightleftarrows \mathrm{Ag}_{(\mathrm{aq})}+\mathrm{Cl}^{-}(\mathrm{aq})\right)$, a aplicação mecânica do princípio de Le Chatelier, sem levar em conta a real natureza dinâmica e as características do equilibrio químico, pode levar o aluno a responder que o aumento da quantidade de 
sólido leva ao aumento da quantidade dos produtos gasosos ou da concentração dos íons dissolvidos devido ao consumo de parte do sólido adicionado.

Considerando a adição de um gás inerte em um sistema gasoso homogêneo, a volume e temperatura constantes, o estudante poderia utilizar erroneamente 0 princípio de Le Chatelier mencionando que a pressão total aumentaria e o estado de equilibrio seria alterado no sentido de favorecer a reação que produz um menor volume (ou menor número de partículas). Entretanto, neste caso, as pressões parciais dos gases permanecem inalteradas e, conseqüentemente, o equilibrio não será afetado (QUÍLEZ-PARDO, 1997 e KATZ, 1961). Vale aqui ressaltar que nenhuma publicação de Le Chatlelier considerou o fato de um gás inerte ser adicionado ao sistema em equilíbrio químico.

Outro exemplo clássico de limitação do emprego princípio pode ser considerado com o exemplo de um equilíbrio químico muito utilizado em livros didáticos, o da produção do gás amônia: $\mathrm{N}_{2(\mathrm{~g})}+3 \mathrm{H}_{2(\mathrm{~g})} \rightleftarrows 2 \mathrm{NH}_{3(\mathrm{~g})}$. Considerando os participantes deste equilíbrio como gases ideais, poderíamos perguntar, por exemplo, qual dos dois sentidos da reação é favorecido (se a formação de produtos ou de reagentes) ao adicionarmos mais gás nitrogênio à mistura gasosa em equilîbrio. Uma aplicação direta do princípio levaria à resposta de que ocorreria uma alteração no estado de equilíbrio no sentido de formação de mais amônia, uma vez que o sistema em equilíbrio deve consumir nitrogênio produzindo mais amônia a fim de "promover uma modificação de condensação (concentração) de sinal contrário àquela resultante da ação exterior" (conforme a primeira formulação do princípio).

Porém, isto só é verdadeiro se considerarmos que a adição foi feita a temperatura e volume constantes (KATZ, 1961 e LEVINE, 1988). Se, por outro lado, a adição for feita a temperatura e pressão total constantes, a adição de certa quantidade de gás nitrogênio promove o aumento da pressão parcial deste gás, que deve ser instantaneamente acompanhada por um aumento do volume do sistema, caso contrário, a pressão total não permanecerá constante (conforme prevê a lei das pressões parciais de Dalton). Neste caso, não é possível predizer se, como resposta à perturbação, haverá formação de reagentes ou produtos através de uma simples análise qualitativa baseada na aplicação direta do princípio de Le Chatelier, pois, o aumento da pressão parcial do gás $\mathrm{N}_{2}$ (reagente) é acompanhado pela diminuição das pressões parciais de gás $\mathrm{H}_{2}$ (reagente) e de gás $\mathrm{NH}_{3}$ (produto). Se, por outro lado, raciocinarmos em termos de concentrações (propriedade literalmente expressa 
na primeira formulação do princípio), concluiríamos que o aumento do volume também provoca, ao mesmo tempo, a diminuição das concentrações de gás $\mathrm{H}_{2}$ (reagente) e de gás $\mathrm{NH}_{3}$ (produto).

Portanto, a simples aplicação princípio de Le Chatelier apresenta uma ambigüidade para este exemplo porque as variações das pressões parciais (ou concentrações) dos gases reagentes $\mathrm{N}_{2}$ e $\mathrm{H}_{2}$ levam a predições opostas (QUíLEZPARDO et al., 1993; ALLSOP E GEORGE, 1984). O princípio em si, na forma com apresentado nas diferentes formulações anteriormente citadas, não permite predizer o comportamento desse sistema frente à alteração a que foi submetido (CHEUNG, 2004).

O tratamento correto desta questão exige uma abordagem termodinâmica rigorosa (DE HEER, 1957 e QUÍLEZ-PARDO, 1996a) ou da comparação da expressão do quociente de reação, Qc, com a expressão da constante de equilíbrio, Kc, (KATZ, 1961; CHEUNG, 2004 e 2009), uma vez que, no equilíbrio:

$$
Q c=\frac{\left(\frac{n_{N H 3}}{V}\right)^{2}}{\left(\frac{n_{N 2}}{V}\right)\left(\frac{n_{H 2}}{V}\right)^{3}}=\frac{n_{N H 3}{ }^{2} V^{2}}{n_{N 2} n_{H 2}{ }^{3}}=K c
$$

em que $V$ é o volume e $n_{i}$ é a quantidade de matéria em número de mols de cada componente. Assim, após a introdução de gás $\mathrm{N}_{2}$, a nova posição do equilîbrio dependerá da razão $V^{2} / n_{N 2}$ presente na expressão de $Q c$.

Se o novo valor da razão $V^{2} / n_{N 2}$ for maior que o valor da razão original na expressão de $K c$, então $Q c>K c$ e haverá a formação de mais reagentes. Caso contrário, será favorecida a reação de formação de amônia (produto). (CHEUNG, 2004 e 2009).

Katz (1961) e Lacy (2005) propõem uma generalização que se pode estabelecer para outras reações químicas, com o objetivo de prever em que sentido se deslocará o equilíbrio, a temperatura e pressão constantes, pela adição de uma determinada quantidade de um reagente ou produto. Em um equilíbrio representado por:

$$
\mathrm{aA}_{(\mathrm{g})}+\mathrm{bB}_{(\mathrm{g})} \rightleftarrows \mathrm{p} \mathrm{C}_{(\mathrm{g})}+\mathrm{q} \mathrm{D}_{(\mathrm{g})}
$$


Define-se $\Delta \mathrm{n}=(\mathrm{p}+\mathrm{q})-(\mathrm{a}+\mathrm{b})$. Ao se adicionar um produto $\mathrm{C}$, o equilíbrio se deslocará para formar maior quantidade de produtos se $X_{c}>\mathrm{p} / \Delta \mathrm{n}$, em que Xc é a fração molar inicial de C neste equilíbrio. (QUíLEZ-PARDO et al., 1993). Uma análise teórica quantitativa deste problema mostra que haverá formação de gás amônia se a fração molar de gás nitrogênio for menor que 0,5. Entretanto, se a fração molar de gás nitrogênio for maior que 0,5 o equilíbrio deverá decompor mais gás amônia para formar mais gases nitrogênio e hidrogênio (Katz, 1961) ${ }^{1}$.

A crença de que o Princípio de Le Chatelier é uma regra segura e infalível também é verificada em professores de Química. De acordo com os Parâmetros Curriculares Nacionais:

[...] uma formação universitária deficiente de alguns docentes origina crenças em algumas "verdades científicas"” da Química tais como a "regra do octeto", o princ ípio de Le Chatelier e a chamada "reação de dupla troca", contribuindo para um caráter de "verdade absoluta e infalível"' da Ciência (BRASIL, 1999).

Os exemplos por hora apresentados mostram exatamente o contrário porque, ao falarmos de princípios da ciência, deve-se levar em conta a construção e reconstrução do conhecimento científico, eliminando-se a idéia de "verdades absolutas e eternas".

${ }^{1}$ A demonstração matemática desta afirmação foge aos objetivos deste trabalho, no entanto a mesma pode ser encontrada em Katz (1961). 


\section{ALTERNATIVAS AO USO DO PRINCÍPIO DE LE CHATELIER}

Junto aos questionamentos da validade geral do princípio de Le Chatelier, suas limitações (DE HEER, 1957, TREPTOW, 1980; GOLD E GOLD, 1984) e os problemas decorrentes de sua aplicação no ensino de química, que muitas vezes se sobrepõe a um correto e completo entendimento por parte de alunos e professores dos fenômenos que envolvem um equilíbrio químico (QUÍLEZ-PARDO, 1997a; QUÍLEZ-PARDO et al., 1993 e QUÍLEZ-PARDO, 1998), vários autores têm procurado alternativas ao ensino desse princípio (DE HEER, 1957; KATZ, 1961; ALLSOP E GEORGE, 1984; QUÍLEZ-PARDO e SOLAZ-PORTOLES, 1998; CASAGARATNA, 2003 e CHEUNG, 2004).

De Heer (1957), por exemplo, sugere que, para cursos elementares, o princípio seja substituído por algumas poucas regras qualitativas, tais como aquelas do equilibrio móvel descritas por Van't Hoff ("um aumento na temperatura promove um deslocamento no equilibrio na direção de absorção de calor, ou seja, favorece a reação endotérmica"). A vantagem, segundo o autor, é de que regras deste tipo têm uma aplicação mais limitada e menos ambiciosa, pois, não buscam uma generalização tão ampla, permitem uma única interpre tação e podem ser justificadas em cursos mais avançados, utilizando-se os princípios da termodinâmica (DE HEER, 1957).

No entanto, além de citar as regras qualitativas de Van't Hoff para variação de temperatura e de pressão, provocada por mudanças de volume em um sistema gasoso a temperatura constante, o autor não chega a formular quais seriam essas regras e quais casos devem ser estudados em cada nível de ensino. A adoção desta estratégia exige, portanto, a seleção dos casos de alterações do estado de equilibrio químico a serem estudados, e a formulação de regras claras, com variáveis bem delimitadas e com poder preditivo apenas para o estudo de cada um destes casos específicos.

É útil também se perguntar se a adoção desta estratégia não pode incorrer no incentivo à simples memorização de regras e o uso de algoritmos para resolver problemas, sem que o aluno compreenda o fenômeno e os conceitos de maneira satisfatória, uma vez que as regras teriam que ser apresentadas como sendo obtidas de forma indutiva através da generalização de resultados de problemas semelhantes. 
Vale lembrar que o princípio de Le Chatelier inclui, em sua formulação comumente apresentada, uma explicação, pois, segundo o mesmo trata-se de uma "reação (do sistema) em um sentido tal que tenda a produzir uma variação de sentido contrário à condição externa modificada" (LE CHATELIER, 1926). Regras qualitativas com a exposta por Van't Hoff compreendem apenas uma generalização restrita com poder preditivo, no entanto, sem poder explicativo. No entanto, vale ressaltar que esta explicação, formulada em 1884, não contém qualquer referência à natureza microscópica do sistema em equilíbrio, o que seria fundamental para a explicação de um fenômeno químico de acordo com o conhecimento atual.

Algumas propostas defendem um uso mais intensivo da expressão matemática da lei do equilíbrio, ou seja, o uso da expressão matemática de $K$ (constante de equilîbrio) e sua comparação com o quociente de reação, $Q$, definido, da mesma forma que $K$, como o produto das concentrações de produtos dividido pelo produto das concentrações de reagentes, sendo as concentrações elevadas aos seus coeficientes estequiométricos, e descrito para o sistema após a alteração de algum dos parâmetros do equilîbrio (KATZ, 1961; ALLSOP e GEORGE, 1984; CHEUNG, 2004). Assim, se $Q=K$, o sistema está equilíbrio e a ação efetuada não promoveu nenhuma alteração do estado de equilibrio (caso da adição de um gás inerte em um equilíbrio gasoso a temperatura e volume constantes), se $Q<K$, será favorecida a formação de produtos e se $Q>K$, será favorecida a formação de reagentes (CHEUNG, 2004).

Allsop e George (1984) usam a lei do equilíbrio para resolver problemas qualitativos que envolvem: mudanças nas concentrações das espécies a volume constante; mudanças da pressão externa; mudanças de volume; adição de gás inerte e adição de espécies em equilíbrio gasoso a pressão e temperatura constantes, através de uma abordagem simples e possível de ser aplicada no ensino médio. No caso de mudanças nas concentrações a volume constante, os autores chamam a atenção para o fato de que tanto as concentrações de reagentes quanto as de produtos serão maiores que aquelas presentes antes da adição de qualquer um dos constituintes, fato claramente observado pela equação de $K$ e pouco compreendido pelos alunos, que tendem a pensar que, em um equilíbrio químico do tipo $A+B \gtrless C$, a adição de $C$ promove a formação de reagentes de maneira que no novo estado de equilíbrio haverá mais $A$ e $B$ e menos $C$ (ALLSOP e GEORGE, 1984; RAVIOLO E MARTÍNEZ-AZNAR, 2003). 
Cheung (2004 e 2009) propõe a mesma abordagem e lembra que não é necessário calcular o valor exato de $Q$ para se fazer qualquer previsão (CHEUNG, 2009), de maneira que não são exigidos muitos cálculos e sim um entendimento mais profundo da lei de equilíbrio e das variáveis nela relacionadas tais como: concentração, quantidade de matéria, pressão, pressão parcial, entre outras. Este último autor chega a declarar que o ensino do princípio de Le Chatelier não se justifica na educação básica, quer seja por sua significância, ou seja, como tópico essencial para o estudo do tema equilíbrio químico, quer seja por sua validade, entendida aqui como precisão (CHEUNG, 2009).

Desta forma, é importante que os professores reflitam a respeito da relevância de toda a programação a ser ensinada e principalmente do tempo programado para cada conteúdo, mesmo aqueles tão consagrados. Além disto, é interessante frisar que, a simples manipulação destas expressões matemáticas defendidas por estes autores pode gerar os mesmos problemas da simples aplicação de regras qualitativas ou do princípio de Le Chatelier, ou seja, a utilização de algoritmos prontos para resolver problemas sem que o estudante reflita sobre os aspectos conceituais pertinentes.

Ao se abordar o efeito da variação da temperatura, a maioria dos trabalhos aponta como caminho o uso da regra de Van't Hoff, quer seja esta expressa como um enunciado qualitativo, como exposto anteriormente (DE HEER, 1957) ou como um enunciado quantitativo do tipo: In $K=(-\Delta H / R T)+$ constante (ALLSOP e GEORGE, 1984; CHEUNG, 2004):

Outros trabalhos apresentam abordagens que só podem ser utilizadas com alunos de nível superior. Dentre estas, há as que defendem o uso da equação de $K$ (KATZ, 1961) ou uma abordagem baseada nos princípios da Termodinâmica (afinidade, grau de avanço da reação, variação de energia livre, potencial químico, etc.) para alunos de curso mais avançados de físico-química (CASAGARATNA, 2003; QUÍLEZ-PARDO e SOLAZ-PORTOLES, 1996a; KEMP, 1987 e TORRES, 2007).

Mesmo diante de tantas críticas ao princípio de Le Chatelier, há uma falta de trabalhos na literatura que procurem verificar a eficiência das propostas acima apresentadas. Quílez-Pardo (1997b) propôs e testou um método alternativo de ensino baseado no uso exclusivo da expressão da constante de equilibrio $(K)$ enfatizando o controle das variáveis envolvidas nos diferentes sistemas estudados. 
O método destinou-se a um grupo de alunos espanhóis do curso equivalente ao último ano do ensino médio brasileiro e foi aplicado um teste padrão para identificar concepções alternativas relacionadas ao uso incorreto do Princípio de Le Chatelier.

Após a instrução foram analisados os resultados de dois grupos: um grupo experimental em que se utilizou apenas a expressão da constante de equilíbrio $(K)$ e um grupo controle, que aprendeu a prever mudanças de estado de equilibrio pelo princípio de Le Chatelier. Os resultados obtidos do teste aplicado aos alunos dos dois grupos mostraram um desempenho superior do grupo experimental em relação ao grupo controle. Ao final do estudo, o autor sugere que se evite o ensino do princípio na educação básica e que sua formulação, de um modo quantitativo e restritivo, seja apresentada apenas em cursos superiores de química, como um teorema derivado dos princípios da termodinâmica (QUíLEZ-PARDO, 1997b). 


\section{ASPECTOS METODOLÓGICOS}

A escolha dos livros analisados neste trabalho se baseou no fato de serem materiais disponíveis no mercado há algum tempo e publicado por editoras comercialmente importantes. Além destes, também foram escolhidos livros produzidos por grupos de pesquisa em ensino de química do Brasil.

Com o intuito de facilitar a identificação da análise utilizaremos, ao longo deste trabalho, as iniciais dos autores dos livros didáticos por meio de siglas. Os livros escolhidos e suas respectivas siglas são apresentados na tabela 1.

Tabela 1: livros didáticos analisados.

\begin{tabular}{|c|c|c|}
\hline № & Livro Didático & Sigla \\
\hline 1 & Química - volume único, de Vera Novais (Atual Editora, 1996) & VN \\
\hline 2 & $\begin{array}{l}\text { Química Série Brasil - volume único, de Antônio Sardella e } \\
\text { Marly Falcone (Editora Ática, 2004) }\end{array}$ & SF \\
\hline 3 & $\begin{array}{c}\text { Química e Sociedade - volume único, vários autores (Editora } \\
\text { Nova Geração, 2005) }\end{array}$ & PEQUIS \\
\hline 4 & $\begin{array}{c}\text { Interações e Transformac̃ões II: livro do aluno, vários autores } \\
- \text { GEPEQ (Edusp, 1995) }\end{array}$ & GEPEQ \\
\hline 5 & $\begin{array}{c}\text { Química na abordagem do cotidiano - volume 2, de Francisco } \\
\text { Miragaia Peruzzo (Tito) e Eduardo Leite do Canto (Editora } \\
\text { Moderna, 2006) }\end{array}$ & TC \\
\hline 6 & $\begin{array}{l}\text { Química para o Ensino Médio - volume único, de Eduardo } \\
\text { Fleury Mortimer e Andréa Horta Machado (Editora Scipione, } \\
\text { 2003) }\end{array}$ & MM \\
\hline 7 & $\begin{array}{l}\text { Química - volume 2, de Ricardo Feltre (Editora Moderna, } \\
\text { 2004) }\end{array}$ & RF \\
\hline 8 & $\begin{array}{c}\text { Química - volume 2, de João Usberco e Edgard Salvador } \\
\text { (Editora Saraiva, 2006) }\end{array}$ & US \\
\hline
\end{tabular}

\subsection{Critérios para análise dos textos}

Considerando que o principal objetivo é a compreensão integral dos conceitos relacionados à mudança de um estado de equilibrio químico, os critérios de análise estão fundamentados sobre como os livros trabalham estes conceitos. 
Uma das partes deste trabalho consistiu em comparar as formulações do princípio presentes nos diferentes livros didáticos, identificando a estrutura de linguagem, a apresentação utilizada para a descrição do princípio e a sua relação com uma das diferentes formulações propostas pelo próprio Le Chatelier.

Além disso, um aspecto fundamental na análise dos livros didáticos será a apresentação e discussão das diferentes variáveis que influenciam o estado de equilibrio químico, tais como: catalisador, concentração de substâncias, pressão e temperatura do sistema. Farão parte destas discussões a análise criteriosa de figuras e gráficos presentes nos livros didáticos em que ilustram a influência das variáveis acima mencionadas.

Por fim, será apresentada uma breve reflexão sobre as situações em que o princípio não pode ser aplicado e ainda se existem algumas alternativas ao princípio, como a utilização da constante de equilibrio para prever e explicar possíveis alterações provocadas pela mudança de alguma variável do sistema.

Vale aqui ressaltar que não foram analisados os capítulos a respeito de equilíbrios de ionização (ácido-base), pH, tampão e hidrólise salina. Portanto, os equilibrios em solução aquosa ficaram restritos apenas ao caso do produto de solubilidade quando se discutem os equilíbrios heterogêneos. Esta escolha foi feita com o objetivo de delimitar a análise e a discussão do presente trabalho.

Após uma leitura preliminar em que foram analisados tópicos, subtítulos, conceitos e exemplos presentes nos diferentes livros didáticos, foi elaborado um instrumento prévio para a análise destes livros e este resultou em dezesseis questões, encontradas no apêndice $A$.

É importante ressaltar que este instrumento contém questões que serviram apenas como referência para formular as discussões ao longo do trabalho e, portanto, não existe uma relação exata entre as questões discutidas neste estudo com as do instrumento de análise. As questões contempladas na análise neste trabalho e que são discutidas ao longo do mesmo são: a) Como o princípio está formulado? b) Qual a estratégia de apresentação do princípio? c) Quais variáveis se discutem nas alterações do estado de equilibrio químico (concentração, pressão, temperatura e adição de um catalizador)? d) São discutidas as limitações da aplicação do princípio de Le Chatelier? e) São apresentadas alternativas ao princípio de Le Chatelier? 


\subsection{Critérios para a análise de ilustrações}

Segundo Johnstone (1993), o aprendizado da Química implica na compreensão de três aspectos fundamentais: a observação dos fenômenos naturais (universo macroscópico), a representação destes em linguagem científica (universo simbólico) e o real entendimento do universo das partículas como átomos, íons e moléculas (universo microscópico). A compreensão e interligação entre estas três interfaces pressupõem o verdadeiro entendimento e o domínio do conhecimento químico em questão, e é comumente representado através do que ficou conhecido como triângulo de Johnstone (figura 1). Com relação ao nível microscópico, Johnstone (2000) ressalta sua importância e a imensa dificuldade em ensiná-lo aos alunos, que por sua vez também terão grande obstáculo em compreendê-lo.

O entendimento real das relações apontadas pelo modelo de Johnstone representa incrementar um valor significativo ao currículo no nível básico e superior inclusive em livros didáticos, manuais de laboratório e figuras ilustrativas (Johnstone, 2004). Neste referido trabalho, Johnstone recomenda que professores de Química criem situações reais que possam mostrar o universo macroscópico ao aluno acompanhado da simbologia química pertinente e, ao mesmo tempo, se utilize de diferentes tipos de figuras, tais como animações de computador e simulações, com 0 objetivo de criar habilidades para a compreensão do nível molecular.

Desta forma, há de se considerar que as ilustrações presentes em livros didáticos constituem-se em importantes recursos para auxiliar no estabelecimento de relações entre os níveis macroscópico, microscópico e simbólico e, consequentemente, para um verdadeiro entendimento de fenômenos químicos. Portanto, ao analisar estas ilustrações, pretendemos verificar como estas auxiliam ou atrapalham a correta compreensão do estudante sobre os conceitos envolvidos.

Vale também lembrar que as imagens desempenham um a papel importante no ensino de ciências, uma vez que a própria conceitualização depende muitas vezes da visualização (JOHNSTONE, 2004). 


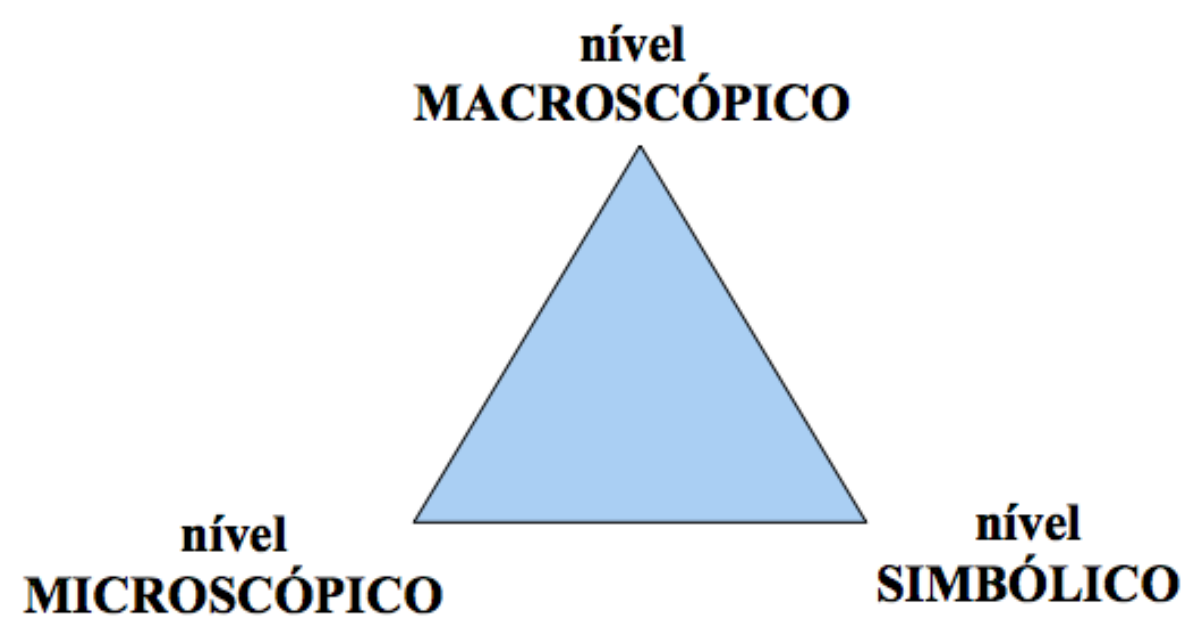

Figura 1: Triângulo de Johnstone. Representação dos universos e níveis de compreensão do conhecimento químico.

Neste trabalho, são considerados e analisados dois tipos de ilustrações presentes nos livros didáticos: gráficos e figuras. Estas discussões foram referenciadas segundo os três universos de compreensão dos fenômenos químicos, representados no triângulo de Johnstone (figura 1). Portanto, esta análise possui o intuito de verificar se as relações entre estes três níveis são de alguma forma representadas ou discutidas, considerando que os objetivos apontados nos Parâmetros Curriculares Nacionais (BRASIL, 1999) só podem ser plenamente atingidos se o aluno for capaz de compreender o fenômeno nestes três níveis de representação.

Devido à grande quantidade de ilustrações presentes nos livros didáticos, foram selecionadas para análise aquelas que estão baseadas em aspectos que possam contribuir para o real entendimento dos conceitos químicos envolvidos ao se modificar o estado de um sistema em equilíbrio. Assim, a ilustração deveria se relacionar a uma alteração do estado de equilíbrio químico e abordar claramente, no mínimo, dois estados distintos: o equilíbrio inicial e o equilibrio modificado. Não foram analisadas ilustrações tais como: fotos de cientistas, fábricas de produção de amônia, analogias relacionadas ao estado de equilibrio, equilíbrio físico de fases e figuras presentes em exercícios propostos. É fundamental ressaltar que as tabelas não estão incluídas na categoria "ilustrações" e, desta forma, não fizeram parte da análise. Entretanto, ao longo do texto, serão apresentadas algumas tabelas consideradas relevantes para a discussão de questões centrais deste trabalho. 


\section{RESULTADOS E DISCUSSÃO}

\subsection{Como o princípio de Le Chatelier está formulado?}

Todos os livros analisados apresentam o Princípio de Le Chatelier como regra qualitativa para prever possíveis alterações em um sistema em equilíbrio químico. $\mathrm{Na}$ tabela 2 são apresentados os enunciados do princípio, tais como aparecem em cada um dos livros didáticos.

Em geral, os enunciados apresentam-se destacados do texto, a única exceção é o livro GEPEQ, cujo princípio é apresentado no corpo do texto que compõe a conclusão do capítulo a respeito de alterações no estado de equilibrio químico (tabela 2).

Pode-se afirmar que todos os enunciados são adaptações da formulação de Ostwald, publicado em 1904, que afirma: "Se um sistema em equilíbrio é submetido a uma perturbação, por meio da qual o equilibrio seja perturbado, uma mudança ocorrerá, se possível, que anule parcialmente a alteração" (OSTWALD, 1904 apud QUÍLEZ-PARDO e SANJOSÉ-LOPEZ, 1996b).

Esta formulação de Ostwald foi elaborada com base no enunciado mais simples e geral presente no Leçons dur le carbone e equivalente também à formulação de 1888, que Le Chatelier reconheceria mais tarde ser inexata (QUíLEZPARDO, 1995).

Mesmo os livros que não mencionam a data do princípio ao longo do texto, (RF, TC, PEQUIS), apresentam esta versão mais geral. O único livro que menciona em seu texto o princípio com a data de 1884 (US) não descreve fielmente o que Le Chatelier apresentou naquele ano, que corresponde à primeira formulação, mais extensa e elaborada que a publicada em 1888. O livro GEPEQ aponta como data da publicação do princípio o ano de 1899, o que não corresponde às datas dos originais citados em revisões da literatura (QUÍLEZ-PARDO e SANJOSÉ-LOPEZ, 1996a).

Como no enunciado de Ostwald, a maioria dos autores prefere utilizar o termo "perturbação" (cinco livros) para se referir à mudança de uma variável no sistema em equil ỉbrio e conclui que ocorre um "deslocamento" (quatro livros) ou "alteração" (dois livros), no sistema com o objetivo de "minimizar", "reduzir" ou "diminuir" (seis livros), ou ainda "neutralizar" esta nova "perturbação" ou "alteração". Pode-se, então, considerar que as formulações apresentadas nos livros: VN, SF, PEQUIS, TC e MM são equivalentes. 
Tabela 2: Enunciados correspondentes à formulação do princípio de Le Chatelier em livros didáticos de química do nível médio

\begin{tabular}{|c|c|c|}
\hline $\begin{array}{l}\text { Sigla do } \\
\text { livro }\end{array}$ & Enunciado & $\begin{array}{l}\text { Data de } \\
\text { formulação do } \\
\text { princípio* }\end{array}$ \\
\hline VN & $\begin{array}{c}\text { "Se um sistema em equilibrio for submetido a uma } \\
\text { perturbação, haverá um des locamento nesse } \\
\text { equilîbrio no sentido de minimizar o efeito da } \\
\text { mudança." (p.397) }\end{array}$ & Não menciona. \\
\hline SF & $\begin{array}{l}\text { "Quando um sistema em equilíbrio sofrer algum tipo } \\
\text { de perturbação externa, ele se deslocará para } \\
\text { minimizar essa perturbação, a fim de atingir } \\
\text { novamente uma situação de equilíbrio." (p.312) }\end{array}$ & Não menciona. \\
\hline PEQUIS & $\begin{array}{c}\text { "Quando uma perturbação externa é imposta a um } \\
\text { sistema químico em equilibrio, esse equilibrio irá se } \\
\text { deslocar de forma a minimizar tal perturbação." } \\
\text { (p.483) }\end{array}$ & 1888 \\
\hline GEPEQ & $\begin{array}{l}\text { “...Quando uma perturbação é imposta a uma } \\
\text { transformação em equilíbrio, este é rompido por um } \\
\text { curto espaço de tempo, estabelecendo-se a seguir } \\
\text { novo estado de equilibrio. Como resposta à } \\
\text { perturbação, ocorrerá a formação ou de maior } \\
\text { quantidade de produtos ou de maior quantidade de } \\
\text { reagentes, estabelecendo-se um outro estado de } \\
\text { equilíbrio. Nessa nova situação de equilibrio, a } \\
\text { concentração do produto poderá ser maior ou menor, } \\
\text { dependendo da perturbação imposta. Essa } \\
\text { generalização, proposta em 1899, é conhecida como } \\
\text { princípio de Le Chatelier..." (p.136) }\end{array}$ & 1899 \\
\hline TC & $\begin{array}{c}\text { "Se uma perturbação é aplicada a um sistema em } \\
\text { equilíbrio, o equilîbrio irá se alterar para reduzir o } \\
\text { efeito da perturbação." (p.453) }\end{array}$ & 1888 \\
\hline MM & $\begin{array}{c}\text { "Se um sistema está em equilíbrio e alguma alteração } \\
\text { é feita em qualquer das condições de equilíbrio, o } \\
\text { sistema reage de forma a neutralizar ao máximo a } \\
\text { alteração introduzida." (p.324) }\end{array}$ & Não menciona. \\
\hline $\mathrm{RF}$ & $\begin{array}{c}\text { "Quanto um fator externo age sobre um sistema em } \\
\text { equilîbrio, este se desloca, procurando minimizar a } \\
\text { ação do fator aplicado." (p.202) }\end{array}$ & 1888 \\
\hline US & $\begin{array}{l}\text { "Quando se aplica uma força em um sistema em } \\
\text { equilíbrio, ele tende a se reajustar no sentido de } \\
\text { diminuir os efeitos dessa força." (p.368) }\end{array}$ & 1884 \\
\hline
\end{tabular}

${ }^{*}$ Conforme mencionado no livro didático. Grifos nossos, ver texto. 
Os enunciados de outros dois autores (RF, US) seguem uma estrutura muito semelhante com a diferença de se referirem a um "fator externo" (RF) ou a uma "força" (US) ao invés do termo "perturbação". O termo "fator externo", embora mais próximo do termo "causa externa" utilizado na primeira formulação original, é ainda mais ambíguo e vago, pois, não define quais são estes fatores e, muito menos sua relação com as propriedades do sistema em equilíbrio, que devem ser considerados. Já o termo "força" sugere paralelos com fenômenos físicos. Uma das críticas normalmente feitas às formulações do Princípio de Le Chatelier é o fato de este ser muitas vezes relacionado com o "princípio da ação e reação", componente da chamada mecânica clássica (QUÍLEZ-PARDO, 1996). Além disto, a literatura aponta que uma das concepções alternativas encontradas a respeito dos equilíbrios químicos é justamente a dificuldade que os alunos apresentam em diferenciar sistemas químicos de físicos, ou seja, muitos estudantes não distinguem a diferença entre o conceito de equilíbrio estático da mecânica (equilíbrio de forças) e o conceito de equilíbrio químico, que é dinâmico em sua natureza (RAVIOLO E MATINEZAZNAR, 2003).

Uma análise da formulação do princípio em livros de Química préuniversitários e universitários espanhóis também apresentou resultados semelhantes nestes aspectos. (QUÍLEZ-PARDO et al.,1993).

Um único livro se destaca pelo fato de não enunciar o princípio de Le Chatelier como os demais (GEPEQ), mas também se utiliza do termo "perturbação" (tabela 2). O interessante neste caso é que o texto explica que "a resposta à perturbação" vai estabelecer um novo estado de equilíbrio, caracterizado pela mudança das quantidades de produtos e reagentes. Embora este texto seja semelhante ao enunciado de Ostwald, neste caso se procura explicar quimicamente o que ocorre constatado no seguinte trecho: "Nessa nova situação de equilíbrio, a concentração do produto poderá ser maior ou menor, dependendo da perturbação imposta." (GEPEQ, p. 136)

Destaca-se também o fato positivo do texto em relacionar as diferenças entre os estados de equilîbrio com as diferenças de concentração de reagentes e produtos. Entretanto, a afirmação de que o equilíbrio é rompido por um "curto espaço de tempo" pode levar o estudante a pensar que uma transformação química necessariamente atinge o equilíbrio rapidamente ou até mesmo de forma instantânea. Vale destacar que esta pode ser uma boa oportunidade para o 
professor discutir a diferença entre aspectos relacionados à espontaneidade e a cinética de uma reação química, como por exemplo, a necessidade de se usar catalisadores em determinados processos químicos.

Em contrapartida, o livro GEPEQ, ao apresentar o princípio discutindo a perturbação imposta de uma variável em específica, no caso a concentração, tem-se uma primeira impressão de que se perde o caráter de generalização do mesmo. Porém, logo em seguida, este livro apresenta uma tabela em que é discutido como as demais variáveis, como pressão total do sistema e temperatura, reagem a uma certa modificação no estado de equilíbrio químico.

Outro aspecto digno de nota é que uma leitura mais atenta da formulação do princípio presente no livro de Ostwald apresenta o seguinte condicionante: "se um sistema em equilíbrio é submetido a uma perturbação, por meio da qual o equilíbrio é perturbado..."(OSTWALD, 1904 apud QUÍLEZ-PARDO e SANJOSÉ-LOPEZ, 1996b). Já no enunciado de Le Chatelier de 1908 lê-se: "A modificação de alguma das condições que podem influir sobre o estado de equilíbrio..." (LE CHATELIER, 1926).

Embora possam ser criticados como vagos e ambíguos (DE HEER, 1957), estes enunciados permitem a conclusão que nem toda a perturbação em um sistema levaria a uma mudança no estado de equilíbrio.

Is to é o que acontece, por exemplo, no caso da adição de um gás inerte a um sistema gasoso a volume e temperatura constantes. Neste caso, há uma perturbação no sistema e uma de suas propriedades aumenta (a pressão total), porém pode-se demonstrar facilmente que as pressões parciais dos gases participantes na transformação (ou suas concentrações) não são alteradas e, desta forma, o equilíbrio químico não é afetado por esta perturbação. Portanto, já que o volume e a temperatura permanecem inalterados, o valor da constante de equilíbrio também permanece o mesmo. (KATZ, 1961)

Nas formulações apresentadas nos livros didáticos este condicionante relacionado ao princípio desaparece (tabela 2). Embora isto possa retirar alguma ambiguidade do princípio, leva a crer que o mesmo se trata de uma lei natural universal e infalível, já que não há qualquer condição que restrinja sua aplicação.

De todo o exposto pôde-se verificar que os livros didáticos, em geral, apresentam os enunciados do princípio de Le Chatelier de forma geral e concisa, utilizando termos de caráter vago e simplificado (DE HEER, 1957 e QUíLEZPARDO, 1997). Estes termos gerais e vagos podem conduzir os alunos a 
predizerem mudanças incorretas em um determinado sistema em equilíbrio, ao aplicar o princípio de Le Chatelier de maneira mecânica. O fato desta aplicação mecânica não exigir um completo entendimento das características que compõe o estado de equilíbrio químico pode promover uma falsa sensação de entendimento, já que a aplicação do princípio parece funcionar de forma lógica.

Vários trabalhos têm apontado que uma das concepções alternativas constantemente encontradas em alunos é a denominada "compartimentalização do equilíbrio", ou seja, muitos estudantes consideram que reagentes e produtos ocupam certas partes delimitadas do sistema (RAVIOLO E MARTÍNEZ-AZNAR, 2003).

Tendo em vista estes apontamentos, procurou-se verificar em quais livros aparecem os termos "desloca para a direita" e "desloca para a esquerda", expressões que podem originar tais concepções alternativas. Metade dos livros continua utilizando esta nomenclatura (RF, TC, SF, US). Um único livro preferiu utilizar os termos: "sentido 1" e "sentido 2", o que também pode causar problemas de aprendizado. Apenas 3 livros (PEQUIS, GEPEQ e MM) utilizam termos com significado químico mais preciso, e, portanto, cientificamente rigorosos, referindo-se ao deslocamento no sentido de "formar produtos" ou "formar reagentes". Vale ressaltar que estes livros são justamente aqueles produzidos por destacados grupos de pesquisa na área do ensino de química, o que demonstra a incorporação no trabalho destes grupos de importantes questões apontadas pela literatura da área.

No entanto, é fundamental ressaltar que o uso de termos cientificamente mais rigorosos pode ser uma condição necessária, mas não suficiente para o correto entendimento do fenômeno. Se o aluno realmente possuir a concepção da "compartimentalização" ele ainda pode pensar que reagentes e produtos ocupam compartimentos distintos. É importante que os professores levem esta possibilidade em consideração e seria interessante que os livros-didáticos ressaltassem o significado correto do uso destes termos. Isto significa deixar claro, por exemplo, que o deslocamento do equilíbrio químico no sentido de formar produtos significa que a quantidade de matéria, em mol de produtos, deve aumentar. 


\subsection{Qual a estratégia de apresentação do princípio?}

Uma das maneiras de se analisar a apresentação de um determinado conceito científico diz respeito à maneira pelo qual o conceito é apresentado e discutido. De uma forma simples, denominaremos de "método dedutivo" a forma de se expor o conceito inicialmente no texto para posteriormente mostrar maneiras de como este conceito é aplicado. Por sua vez, chamaremos de "método indutivo" o caminho oposto, ou seja, se apresenta primeiramente as aplicações de um determinado conceito, e por meio destas, induz o leitor a definir o conceito, que é apresentado ao final do texto.

Assim sendo, analisou-se a estratégia que cada livro didático adotou quanto à maneira de se introduzir, ao longo do texto, o conceito do princípio de Le Chatelier e, se esta apresentação está justificada de alguma maneira.

O método indutivo é o preferido de metade dos livros didáticos analisados, conforme os dados mostrados na tabela 3, porém as estratégias utilizadas para se justificar a apresentação do princípio são bem distintas. O livro PEQUIS se utiliza da velocidade das reações químicas e da teoria das colisões para explicar como o equilibrio reagirá à uma determinada mudança de temperatura, concentração e pressão. Neste sentido, podemos destacar tais justificativas nos seguintes trechos: "um aumento de temperatura, em geral, implica aumento na rapidez de uma reação" (PEQUIS, p.478). E segue explicando:

Dessa forma, suas colisões têm maior probabilidade de resultar em reações. Assim, tanto a rapidez da reação direta como a da reação indireta crescem com o aumento de temperatura. Entretanto, a reação que ocorre com absorção de calor (endotérmica) aumenta de forma mais acentuada. (PEQUIS, p.478)

O efeito da variação da concentração aparece na frase seguinte: "um aumento na concentração dos reagentes resulta em mais espécies reativas para colisões, provocando um aumento na rapidez da reação." (PEQUIS, p.480) 
Tabela 3: Quadro síntese com as estratégias de apresentação do princípio de Le Chatelier e as respectivas justificativas

\begin{tabular}{|c|c|r|}
\hline Sigla & Método & Justificativas apresentadas \\
\hline PEQUIS & indutivo & aspectos cinéticos (com menção à teoria das colisões) \\
\hline MM & indutivo & dados empíricos do processo de obtenção de amônia \\
\hline TC & indutivo & comparação entre Qc e Kc e dados empíricos \\
\hline GEPEQ & $\begin{array}{c}\text { indutivo } \\
\text { dados empíricos e aspectos cinéticos (com menção à teoria } \\
\text { das colisões) }\end{array}$ \\
\hline SF & $\begin{array}{c}\text { indutivo } \\
\text { dedutivo }\end{array}$ & $\begin{array}{r}\text { Princípio de Le Chatelier, manutenção de Kc e aspectos } \\
\text { cinéticos }\end{array}$ \\
\hline US & dedutivo edivo & aspectos cinéticos (sem menção à teoria das colisões) \\
\hline RF & dedutivo & $\begin{array}{r}\text { Princípio de Le Chatelier e aspectos cinéticos } \\
\text { (com menção à teoria das colisões) }\end{array}$ \\
\hline
\end{tabular}

Por fim a variação de pressão é justificada da seguinte maneira:

O aumento de pressão de um sistema gasoso, a uma temperatura constante, implica no aumento da pressão dos gases presentes... com isso, haverá maior número de colisões entre os reagentes, favorecendo a reação direta, ou seja, deslocando o equilíbrio no sentido em que há menor número de moléculas. (PEQUIS, p.481)

Neste último caso, diferentemente dos anteriores, os autores demonstraram um maior rigor no controle de todas as variáveis modificadas ao explicitar que a mudança de pressão aconteceu sob temperatura constante. Outro destaque importante deste livro é o fato de que é o único que apresenta o princípio de Le Chatelier antes da introdução da expressão da constante de equilíbrio e os referidos cálculos quantitativos relacionados aos equilibrios químicos.

O livro MM apresenta o princípio de Le Chatelier através da análise de um importante processo químico industrial, a obtenção do gás amônia. Os autores adotam uma estratégia de se apresentar um problema químico existente no final do século XIX devido ao aumento do consumo de alimentos, principalmente na Europa. 
Desta forma, era fundamental naquela época aumentar o baixo rendimento do processo de obtenção da amônia, composto utilizado na produção de fertilizantes. Assim, este livro destaca que este problema foi solucionado por dois cientistas do início do século XX, Fritz Haber e Carl Bosch, que alteraram as condições de temperatura e pressão no equilíbrio de produção de amônia a partir da transformação química entre os gases nitrogênio e hidrogênio, possibilitando um acréscimo no rendimento desta reação. A partir deste caso, o livro MM apresenta um quadro que mostra como as alterações de pressão e temperatura influenciam na porcentagem de amônia obtida e propõe algumas questões durante o texto.

\begin{tabular}{|c|c|c|c|c|}
\hline $\begin{array}{c}\text { Pressão }(\mathrm{atm}) \Rightarrow \\
\begin{array}{c}\text { Temperatura }\left({ }^{\circ} \mathrm{C}\right) \\
\Downarrow\end{array}\end{array}$ & 200 & 300 & 400 & 500 \\
\hline 400 & 38,7 & 47,8 & 58,9 & 60,6 \\
\hline 450 & 27,4 & 35,9 & 42,9 & 48,8 \\
\hline 500 & 18,9 & 26,0 & 32,2 & 37,8 \\
\hline 550 & 12,8 & 18,4 & 23,5 & 28,3 \\
\hline 600 & 8,80 & 13,0 & 17,0 & 20,8 \\
\hline
\end{tabular}

Quadro 13-3. Percentagens de amônia formada a partir de uma mistura de $\mathrm{H}_{2}(\mathrm{~g})$ e $\mathrm{N}_{2}(\mathrm{~g})$ na proporção de 3:1.

Figura 2: tabela extraída do livro MM mostrando a produção percentual de amônia

A partir da observação da figura 2, os autores propõem as seguintes questões:

[...] a produção de amônia aumenta ou diminui a pressão do sistema? Por quê? Considerando cada valor de temperatura, o que acontece com a percentagem de amônia formada quando se aumenta a pressão sobre o sistema? Considerando cada valor de pressão, o que acontece com a percentagem de amônia formada quando se aumenta a temperatura do sistema? (MM, p.323) 
Assim, ao consultar a figura 2 e ao fornecer respostas às questões propostas, o leitor é levado a concluir como as alterações de pressão e temperatura alteram o estado de equilíbrio químico.

O livro MM não faz referência explícita à velocidade das reações ou à teoria das colisões, mas relembra o conceito relacionado ao estudo dos gases ao dizer que a presença de um maior número de moléculas implica em uma maior pressão exercida por um determinado gás. Ao final de toda a explicação, a regra geral do princípio de Le Chatelier é apresentada (transcrição contida na tabela 1) e, após esta descrição, os autores salientam que podemos extrapolar as conclusões anteriormente citadas para variações de concentração de reagentes ou produtos.

A alternativa apresentada pelo livro TC se diferencia dos livros anteriores porque utiliza a comparação do valor da constante de equilíbrio em termos de concentração $\left(K_{c}\right)$ com o valor do quociente de concentrações $\left(Q_{c}\right)$ para determinar se o sistema está ou não em equilíbrio. Para estudar o efeito da concentração, os autores apresentam casos em que o sistema apresenta valor numérico diferente do valor da constante $K_{c}$, ou seja, um sistema que não está no estado de equilîbrio químico. A seguir, justificam que este sistema será deslocado no sentido de se atingir exatamente o valor numérico de $\mathrm{K}_{\mathrm{c}}$. Após estas análises, são apresentadas generalizações sobre como o sistema irá reagir devido a um aumento ou diminuição da concentração de um componente.

Ao apresentar o deslocamento de equilíbrio por variação de pressão e temperatura, o livro TC altera a estratégia de apresentação dos conceitos ao divulgar dados empíricos através de um mesmo equilíbrio $\left(\mathrm{N}_{2} \mathrm{O}_{4} \rightleftarrows \mathrm{NO}_{2}\right)$. Estes dados empíricos levam às conclusões de como variações de temperatura e pressão alteram um equilíbrio químico. Para o real entendimento destas conclusões, os alunos precisariam compreender de maneira coerente conceitos relacionados ao estudo dos gases e aspectos termoquímicos. Porém, em seguida, para ambas variáveis, os autores mostram um exemplo numérico semelhante ao apresentado para variações de concentração, ou seja, a comparação de um valor numérico de quociente de concentrações $\left(Q_{C}\right)$ de um sistema que não está em equilíbrio até o mesmo alcançar o valor da constante de equilíbrio $\left(K_{c}\right)$, fornecido durante o texto.

Portanto, percebe-se uma inversão na explicação destes dois fatores, pressão e temperatura, comparando-se com o efeito da concentração. É importante 
frisar que até este momento não se faz qualquer menção ao princípio de Le Chatelier. Este livro não menciona explicações baseadas em aspectos cinéticos ou na teoria das colisões, e deixa a impressão de que as alterações dos equilíbrios são justificadas principalmente no objetivo de se obedecer à expressão matemática e atingir o valor numérico de $K_{c}$ através da alteração do numerador e denominador da fórmula matemática. Tendo em vista esta análise, é importante ressaltar que existe a possibilidade de ocorrer uma substituição de algoritmos na concepção dos estudantes, ao trocarmos uso indiscriminado do princípio de Le Chatelier pela simples avaliação do valor numérico da constante de equilíbrio $K_{c}$.

Mesmo que se faça uso das estratégias presentes nestes algoritmos, devese priorizar o real entendimento dos conceitos químicos envolvidos. Ao final destas explicações, os autores apresentam o princípio, o que caracteriza uma maneira indutiva de apresentação do mesmo.

Assim como os livros anteriores, o livro GEPEQ também induz o leitor às conclusões relativas ao princípio de Le Chatelier e se utiliza de dados experimentais para explicar as alterações provocadas nos equilíbrios químicos. No estudo da mudança de temperatura, os dados empíricos são mostrados em forma de tabelas e seguem-se questões que levam o aluno a responder qual transformação é favorecida, aquela que fornece ou retira calor do sistema. Para mudanças de concentração, retoma-se um experimento mostrado anteriormente no texto e propõe-se a coleta de novos dados experimentais para aprofundar as ideias sobre como a mudança do fator concentração altera o estado de equilíbrio. A seguir, novas questões são propostas no item denominado "conclusões" e, a última questão, solicita ao aluno que, a partir de suas observações, resuma como as alterações na concentração de reagentes e produtos influenciam nos sistemas em equilíbrio químico. Os dados empíricos também são analisados para estudar mudanças de pressão no sistema e conceitos sobre o estudo dos gases são retomados durante o texto, tais como a equação geral dos gases ideais e a Lei de Boyle. Somente no caso do estudo da variável pressão, o livro GEPEQ propõe explicações baseadas em aspectos cinéticos e na teoria das colisões.

O livro VN faz uma mistura dos dois métodos de apresentação do princípio, conforme a variável analisada. Para os fatores temperatura e concentração de um participante do equilibrio, a autora apresenta dados de dois experimentos que levam às conclusões desejadas e, a seguir, cita que a interpretação dos resultados destes 
experimentos leva à generalização proposta pelo princípio de Le Chatelier. Após a apresentação do princípio, a autora diz textualmente que irá aplicá-lo na seguinte frase: "vamos aplicar o princípio de Le Chatelier a três tipos de perturbações:"

$E$, de forma coerente com a descrição do princípio, refere-se a esta aplicação, para mudanças de concentração, utilizando um sistema genérico e a respectiva explicação, expressas a seguir:

$$
x X+y Y \rightleftarrows z Z+w W
$$

Se aumentarmos a concentração de X, para minimizar tal ação o sistema responderá consumindo parte da substância $X$ acrescentada, por reação com $\mathrm{Y}$, e, consequentemente, obteremos maior quantidade de produtos (Ze W). (VN, p.397)

Em seguida, ainda referindo-se às mudanças de concentração, o livro apresenta a expressão da constante de equilíbrio e justifica a alteração do equilibrio através da manutenção do valor desta constante, visualizada abaixo:

$$
K c=\frac{[Z]^{z}[W]^{w}}{[X]^{x}[Y]^{y}}
$$

A explicação é descrita no livro da seguinte forma: "aumentar [X] significaria aumentar 0 denominador. Para que $K_{c}$ permaneça constante, $[\mathrm{Y}]$ diminui, aumentando [Z] e [W]. O inverso é semelhante." (VN, p.397) Esta explicação não diz que a temperatura do equilíbrio também deve permanecer a mesma para que o valor de $K_{c}$ não seja alterado.

Para exemplificar a manutenção da constante de equilíbrio, a autora mostra uma figura que ilustra outro equilíbrio genérico gasoso $(A \rightleftarrows B$ ), em que a reação direta é denominada reação 1 e a reação inversa de reação 2 (figura 3).

A explicação da figura 3 mostra justificativas baseadas em aspectos cinéticos com menção à teoria das colisões e nota-se que, tanto a explicação da expressão de $K_{c}$ mencionada anteriormente quanto a da figura 3 , apresentam uma preocupação em enfatizar a manutenção da constante de equilíbrio. Entretanto, é 
importante frisar que este novo equilíbrio genérico, presente na figura 3 , e o equilîbrio genérico anterior, não mencionaram que a temperatura permaneceu constante durante a perturbação externa de se adicionar o produto $B$. Um aspecto positivo desta figura é a identificação e análise dos três momentos presentes em uma alteração de equilíbrio químico, ou seja, o equilíbrio inicial, a perturbação e o equilîbrio final.

Como veremos mais adiante, geralmente, estas três etapas aparecem em alguns livros didáticos na forma de gráficos de concentração dos participantes do equilỉbrio em função do tempo, com destaque para o momento da perturbação. Dentre os livros analisados este é o único que apresenta uma representação microscópicas destas etapas, onde, as partículas dos constituintes do sistema são representadas por "bolinhas coloridas", de foram a ilustrar a manutenção da constante de equilíbrio.

Analise a ilustração referente ao sistema:
$\mathrm{A}_{(\mathrm{g})} \underset{2}{\stackrel{1}{\rightleftarrows} \mathrm{B}_{(\mathrm{g})}}$
$\mathrm{K}=\frac{[\mathrm{B}]}{[\mathrm{A}]}$

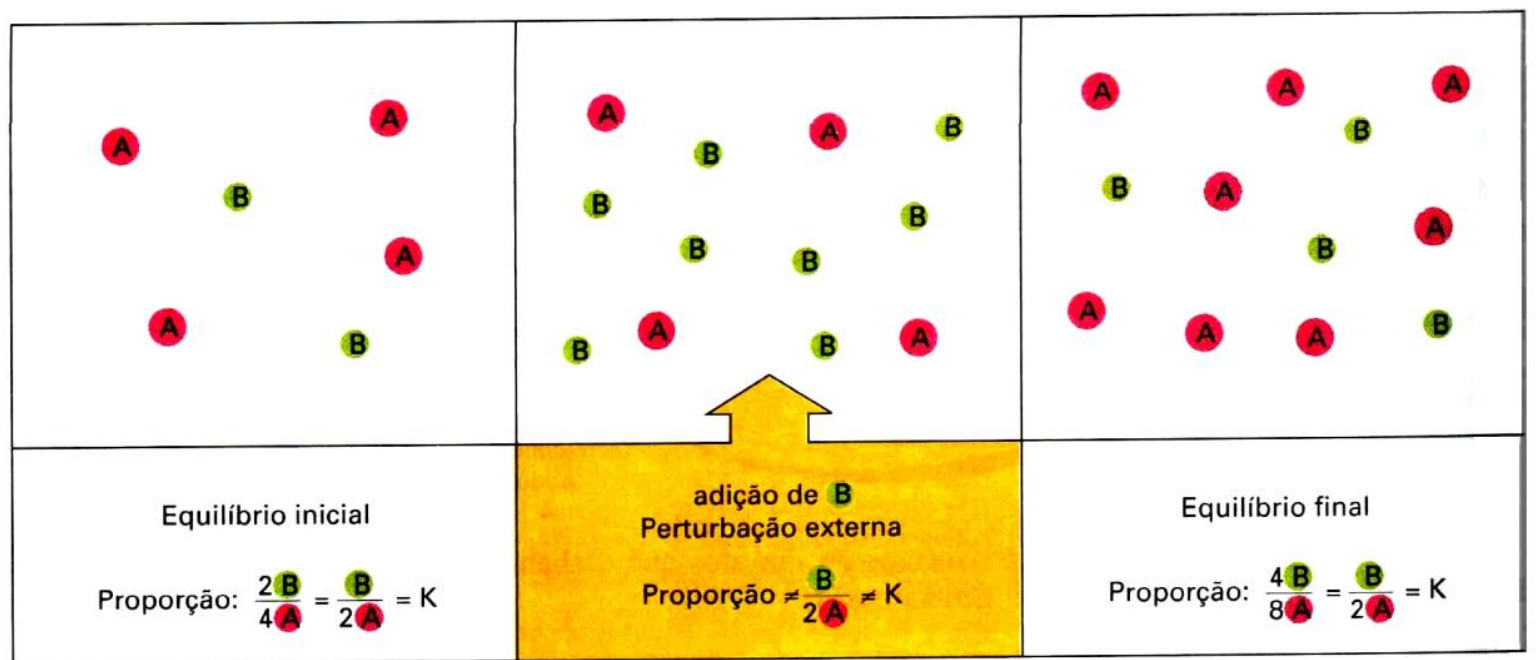

Note que as unidades de B acrescentadas propiciaram maior número de colisōes, aumentando a velocidade da reação 2. Com isso, parte das unidades $B$ são convertidas em $A$, e a proporção inicial entre moléculas (1B:2A) se mantém.

Figura 3: ilustração que mostra a perturbação de um equilíbrio químico presente no livro VN

Tal como a mudança de concentração, o livro VN aplica o princípio de Le Chatelier para alterações de pressão e temperatura, como observado nos seguintes trechos: 
um aumento de pressão...haverá uma redução da pressão e, consequentemente, o efeito perturbador (aumento de pressão) será minimizado."... "o acréscimo de calor desloca o equilíbrio...já que esta absorve parte do calor, reduzindo tal efeito. ( VN, p.398)

Um aspecto a salientar diz respeito aos cuidados que o professor deve tomar ao apresentar uma ilustração como no exemplo da figura 3. Aspectos importantes devem ser discutidos neste exemplo, tais como a representação de bolinhas coloridas e a ausência do mecanismo de reações. Além disto, o professor deve deixar claro que as bolinhas estão em constante movimentação para provocar as colisões descritas na explicação da figura. Desta forma, podemos discutir alguns aspectos de como o aluno "enxerga" a ilustração, enfatizando os aspectos positivos e apresentando as suas limitações.

Outra consideração importante a fazer seria que, mesmo que não sejam percebidas as leis ponderais na ilustração, como a conservação de massas, elas ainda continuam válidas para o exemplo em questão.

A utilização do método dedutivo é o preferido de apenas três dos oito livros didáticos. A justificativa utilizada pelo livro SF relaciona as variações de temperatura com a Lei de Van't Hoff, as mudanças na pressão com a Lei de Robin e as alterações na concentração com a Lei de Guldberg-Waage. O fato de se mencionar o nome destas leis em títulos que precedem as explicações pode transmitir a idéia de que aquilo que será discutido em seguida não poderá ser questionado, pois os fundamentos da explicação estão fundamentados em leis, também caracterizadas como "verdades científicas".

O livro diz textualmente: "a influência de cada um desses fatores no equilibrio é regida por uma lei específica, como indicado a seguir" (SF,p.312). Ao analisar a mudança de temperatura, os autores explicam sucintamente que o aumento de temperatura favorece a reação que absorve calor e a diminuição da mesma favorece a reação que libera calor. Desta forma, nesta explicação não se retoma a definição do princípio de Le Chatelier apresentada anteriormente.

Ao propor explicações para mudanças de pressão, os autores não escrevem explicitamente que o aumento de pressão deverá provocar um deslocamento no sentido de "minimizar esta perturbação", ou seja, de diminuir a pressão total do 
sistema. Simplesmente este raciocínio deve estar subentendido, como se observa no seguinte trecho do livro: "o aumento de pressão provoca o deslocamento no sentido da reação que se realiza com contração de volume" (SF, p.313).

É provável que este salto em duas variáveis distintas, pressão e volume, possa gerar questionamentos por parte dos alunos. Com relação às explicações para mudanças de concentração, destaca-se o seguinte trecho: "haverá aumento da velocidade da reação que consome $0 \mathrm{O}_{2(\mathrm{~g})}$ até que as novas quantidades das espécies estejam novamente em equilíbrio" (SF,p.313).

Portanto, as justificativas de apresentação do princípio aparecem apenas para mudanças de concentrações, apesar de o livro não explicar este aumento de velocidade do ponto de vista da teoria das colisões. Assim, apesar de se utilizar da estratégia de apresentar o princípio antes da discussão sobre as variáveis que alteram um estado de equilíbrio, o livro SF poderia mencioná-lo ao final de todas estas explicações, sem prejudicar o entendimento dos conceitos relacionados. Uma alternativa sempre pertinente é o trabalho cuidadoso do professor envolvendo este aspecto.

O método dedutivo é utilizado pelo livro US, que justifica as alterações de concentração através de conceitos cinéticos e da teoria das colisões. Com relação à variável pressão, o livro retoma o conceito do princípio apresentado, como podemos perceber na seguinte frase: "quando, a uma temperatura constante, aumentamos a pressão sobre o equilíbrio gasoso, ele se desloca no sentido da reação capaz de diminuir essa pressão e vice-versa" (US,p.370).

Em seguida, os autores explicam como o equilíbrio reage a um aumento ou diminuição de pressão relacionando esta variável com número de mol e o volume do sistema. Ao discutir o fator temperatura, o princípio também é lembrado: "quando aumentamos a temperatura, favorecemos a reação que absorve calor, a fim de minimizar seus efeitos". (US, p.372)

Ainda utilizando o mesmo método, RF justifica a apresentação do princípio por mais de uma estratégia. Ao analisar a influência da concentração faz-se a comparação entre o valor de $Q_{r}$, que o autor denomina quociente de reação, e a constante de equilíbrio $K_{c}$ por meio de resultados experimentais, mesma estratégia utilizada pelo livro TC. Além disto, o livro também se utiliza, sem maior aprofundamento, de conceitos cinéticos ao dizer que "a reação direta se acelera em relação à inversa", um diferencial em relação ao livro TC. 
Ao final das análises o princípio de Le Chatelier é relembrado pelo autor, que salienta que as conclusões do princípio são “...bem mais simples..." como no tópico a seguir: "adicionando qualquer participante, o equilíbrio se desloca no sentido de consumi-lo (tendendo a minimizar o efeito da adição)" (RF, p.204). A retirada de um participante segue o mesmo exemplo de explicação.

Por meio da apresentação de dados empíricos são abordadas as justificativas para variações de pressão e temperatura e, para ambos os casos, os conceitos do princípio são retomados ao final das explicações de forma análoga ao apresentado para o fator concentração, como no trecho a seguir: "a redução da pressão total desloca o equilíbrio no sentido de maior volume, pois o aumento de volume minimiza a redução da pressão." (RF, p.205) É importante salientar que o livro não se utiliza de uma explicação mais detalhada baseada em aspectos cinéticos e na teoria das colisões.

\subsection{Quais variáveis se discutem nas mudanças de equilíbrios químicos?}

A tabela 4 mostra as variáveis que afetam um equilibrio químico encontradas nos livros didáticos. Observa-se que todos os livros discutem as mudanças de concentração de reagentes e ou produtos, pressão total e temperatura do sistema.

Em contrapartida, a adição de gás inerte somente é abordada por apenas dois dos oito livros didáticos analisados.

Tabela 4: Variáveis que alteram os equilíbrios químicos presentes nos livros didáticos

\begin{tabular}{|c|c|c|}
\hline Variável alterada & No de livros & Sigla do livro \\
\hline Concentração, pressão e temperatura & 8 & $\begin{array}{c}\text { VN, SF, PEQUIS, GEPEQ, } \\
\text { TC, MM, RF, US }\end{array}$ \\
\hline Presença de catalisador & 6 & VN, SF, GEPEQ, TC, RF, US \\
\hline Adição de gás inerte & 2 & RF, US \\
\hline $\begin{array}{c}\text { Adição de um sólido a um equilíbrio } \\
\text { heterogêneo }\end{array}$ & 4 & US, RF, TC, SF \\
\hline
\end{tabular}


Com relação às figuras analisadas referentes às estas variáveis, foram encontradas 39 ilustrações (tabela 5), das quais a grande maioria (14) se refere a alterações em alguma concentração dos participantes do equilíbrio; 10 ilustrações sobre modificações de pressão e apenas 7 dizem respeito à variação da temperatura e outras 7 referem-se à adição de um catalisador.

Tabela 5: número de ilustrações dos livros sobre as alterações sofridas por um equilibrio químico

\begin{tabular}{|c|c|c|c|c|c|}
\hline Sigla do livro & Concentração & Pressão & Temperatura & Catalisador & Total \\
\hline VN & 3 & 1 & 1 & 0 & 5 \\
\hline PEQUIS & 1 & 1 & 1 & 0 & $4^{*}$ \\
\hline GEPEQ & 1 & 3 & 0 & 0 & 4 \\
\hline TC & 3 & 2 & 2 & 3 & 10 \\
\hline MM & 0 & 0 & 0 & 0 & 0 \\
\hline RF & 1 & 2 & 2 & 2 & 7 \\
\hline US & 5 & 1 & 1 & 2 & 9 \\
\hline SF & 0 & 0 & 0 & 0 & 0 \\
\hline Total & 14 & 10 & 7 & 7 & 39 \\
\hline
\end{tabular}

*esta figura contem pla 3 variáveis simultaneamente (concentração, pressão e temperatura)

O livro PEQUIS mostra uma figura em que as três variáveis são abordadas simultaneamente e somente dois livros não apresentam ilustrações sobre alterações em equilibrios químicos (MM,SF).

Com relação à uniformidade na quantidade figuras por variável modificada, o livro PEQUIS apresenta igualdade nesta distribuição e os livros RF, TC e VN existe a diferença de apenas uma figura entre as variáveis. Em contrapartida os livros US e GEPEQ apresentam mais figuras sobre alterações de concentração (quatro a mais) e pressão (duas a mais), respectivamente. Este último livro (GEPEQ) não apresenta ilustração para a variável temperatura.

Estas 39 ilustrações foram divididas em três grandes grupos: gráficos, figuras de sistemas reais (macroscópicas) e ilustrações a nível molecular (microscópicas). Como foram encontradas figuras que misturaram os níveis macro e microscópico, foi necessária a criação de um quarto grupo (macro e microscópico). 
Os resultados obtidos da análise de cada livro estão expressos na tabela 6 . Pode-se observar a grande maioria das figuras, $85 \%$ do total, correspondem aos gráficos (46\%) e as figuras de sistemas macroscópicos (38\%). Somente 15\% (seis figuras) do total das ilustrações presentes nos livros abordam algum tipo de modelo de partículas que representam o universo microscópico.

Tabela 6: número de gráficos e ilustrações presentes no nível macroscópico e molecular

\begin{tabular}{|c|c|c|c|c|c|}
\hline Sigla do livro & Gráficos & $\begin{array}{c}\text { Figuras } \\
\text { Macroscópicas }\end{array}$ & $\begin{array}{c}\text { Figuras } \\
\text { Microscópicas }\end{array}$ & $\begin{array}{c}\text { Figuras } \\
\text { Macroscópicas } \\
\text { e } \\
\text { Microscópicas }\end{array}$ & Total \\
\hline VN & 0 & 3 & 1 & 1 & 5 \\
\hline PEQUIS & 0 & 3 & 1 & 0 & 4 \\
\hline GEPEQ & 1 & 1 & 1 & 1 & 4 \\
\hline TC & 5 & 5 & 0 & 0 & 10 \\
\hline MM & 0 & 0 & 0 & 0 & 0 \\
\hline RF & 6 & 1 & 0 & 0 & 7 \\
\hline US & 6 & 2 & 0 & 1 & 9 \\
\hline Total & 18 & 15 & 3 & 3 & 39 \\
\hline
\end{tabular}

Dentre esta minoria, apenas três figuras, apresentam simultaneamente representações do universo macroscópico e microscópico, aspecto que será discutido com maior ênfase posteriormente.

Portanto, somente três livros (VN, PEQUIS e GEPEQ) tentam explicar por meio de ilustrações, do ponto de vista da mudança do equilíbrio, o que efetivamente ocorre no nível particular da matéria (microscópico), e com a presença de apenas 3 figuras (somente $8 \%$ do total).

\subsubsection{As mudanças de concentração}

A análise da variação da concentração de uma substância em um equilíbrio químico é tratada em todos os livros e os casos mais comuns são exemplos em solução aquosa ou reações gasosas que ocorrem em um volume total constante. 
Nestes casos, o Princípio de Le Chatelier pode ser aplicado literalmente: "aumentando a concentração de um participante, o equilíbrio se desloca na direção de seu consumo [...]" (TC, p.439). Em nenhum dos livros são abordados os casos em que a aplicação do princípio pode levar a conclusões equivocadas, como na adição de um constituinte a pressão constante (KATZ, 1961 e QUILEZ et al., 1993) ou no caso da diluição de uma solução aquosa em equilíbrio químico. Neste último, o aumento do volume do sistema provoca a diminuição simultânea de todas as concentrações dos participantes do equilíbrio e, desta maneira, o sentido da alteração do estado de equilíbrio só pode ser verificado através da análise correta da equação da constante de equilíbrio $K_{c}$ (TYSON et al., 1999; ALLSOP e GEORGE, 1984).

Um exemplo deste problema da diluição pode ser aplicado para o caso do equilibrio de ionização de um ácido fraco monoprótico: $H A_{(a q)} \rightleftarrows H_{(a q)}^{+}+A_{(a q)}^{-}$. Pode-se demonstrar facilmente que $K a=\left(n_{H_{+}} \cdot n_{A_{-}} / n_{H A}\right) \cdot 1 / V$, portanto, a diluição da solução (aumento do volume total, V) leva ao aumento da ionização do ácido HA, uma vez que para se manter o valor de $\mathrm{K}_{\mathrm{a}}$ constante, o sistema deve reagir de modo a aumentar $\mathrm{n}_{\mathrm{H}^{+}}$e $\mathrm{n}_{\mathrm{A}}{ }^{-}$e diminuir $\mathrm{n}_{\mathrm{HA}}$ (ALLSOP e GEORGE, 1984).

Com relação às ilustrações que dizem respeito à variável concentração, metade dos livros (TC, GEPEQ, US e RF) mostra gráficos a respeito da variação da concentração no estado de equilíbrio em questão.

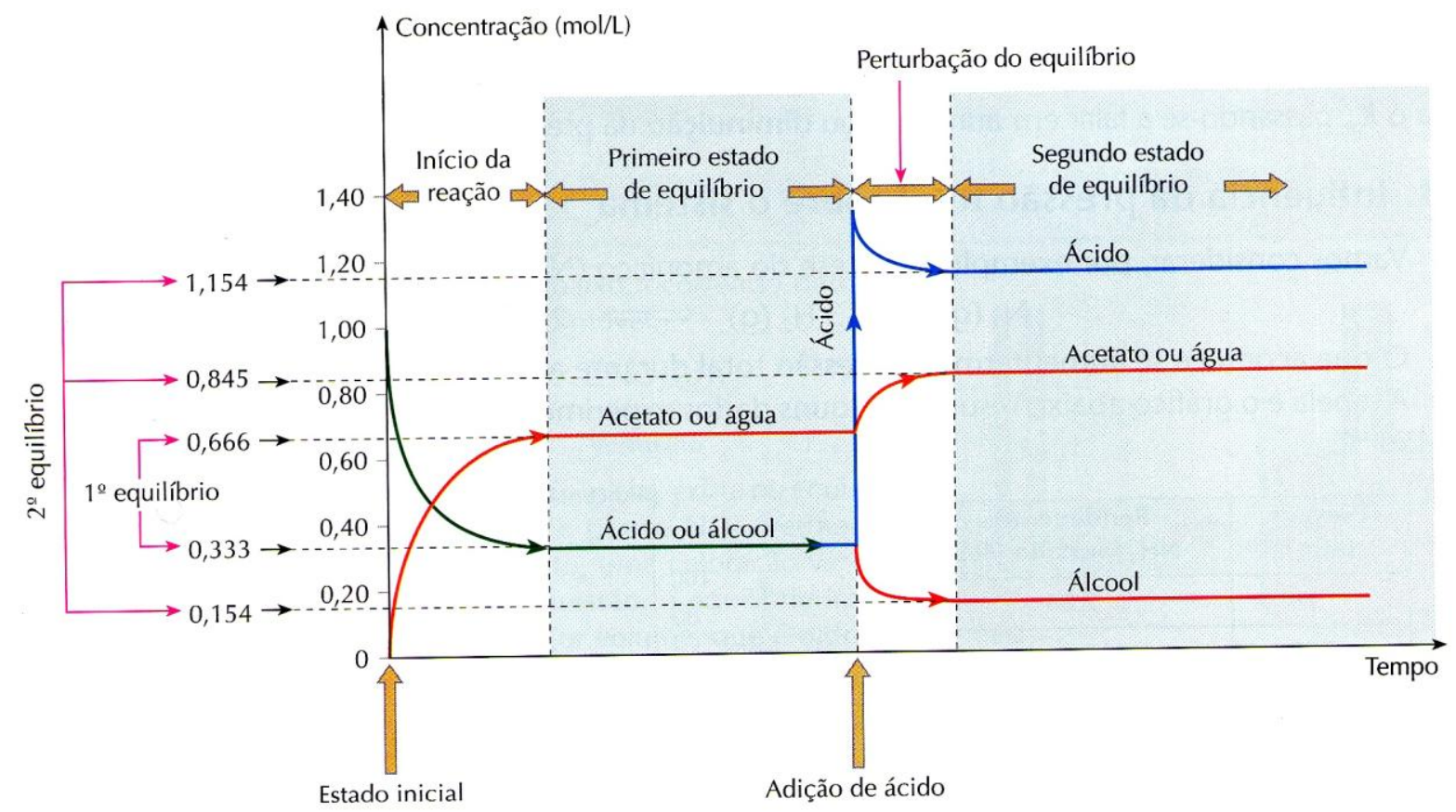

Figura 4: llustração do livro RF sobre a alteração da concentração em um equilíbrio químico 
Neste âmbito, os livros (TC e RF) mostram uma preocupação em apresentar no gráfico todas as etapas pertinentes ao entendimento global do processo de perturbação no equilibrio químico: o início da reação, o estabelecimento do primeiro equilibrio, a perturbação imposta e o estabelecimento de um novo estado de equilibrio (figura 4). Em contrapartida, os livros (GEPEQ e US) iniciam esta análise somente a partir do estado de equilibrio, ocultando o início da reação.

Isto pode causar certa confusão ao aluno porque se deve deixar claro o fato de que a não visualização do início da reação não significa que o estado de equilibrio químico é o ponto de partida de qualquer transformação química.

No livro RF, junto ao gráfico apresentado na figura 4, é apresentada uma figura que ilustra macroscopicamente e indica as quantidades em mol dos participantes em quatro diferentes estágios: sistema inicial, primeiro equilibrio, perturbação do equilíbrio e o estabelecimento do segundo equilíbrio (figura 5).

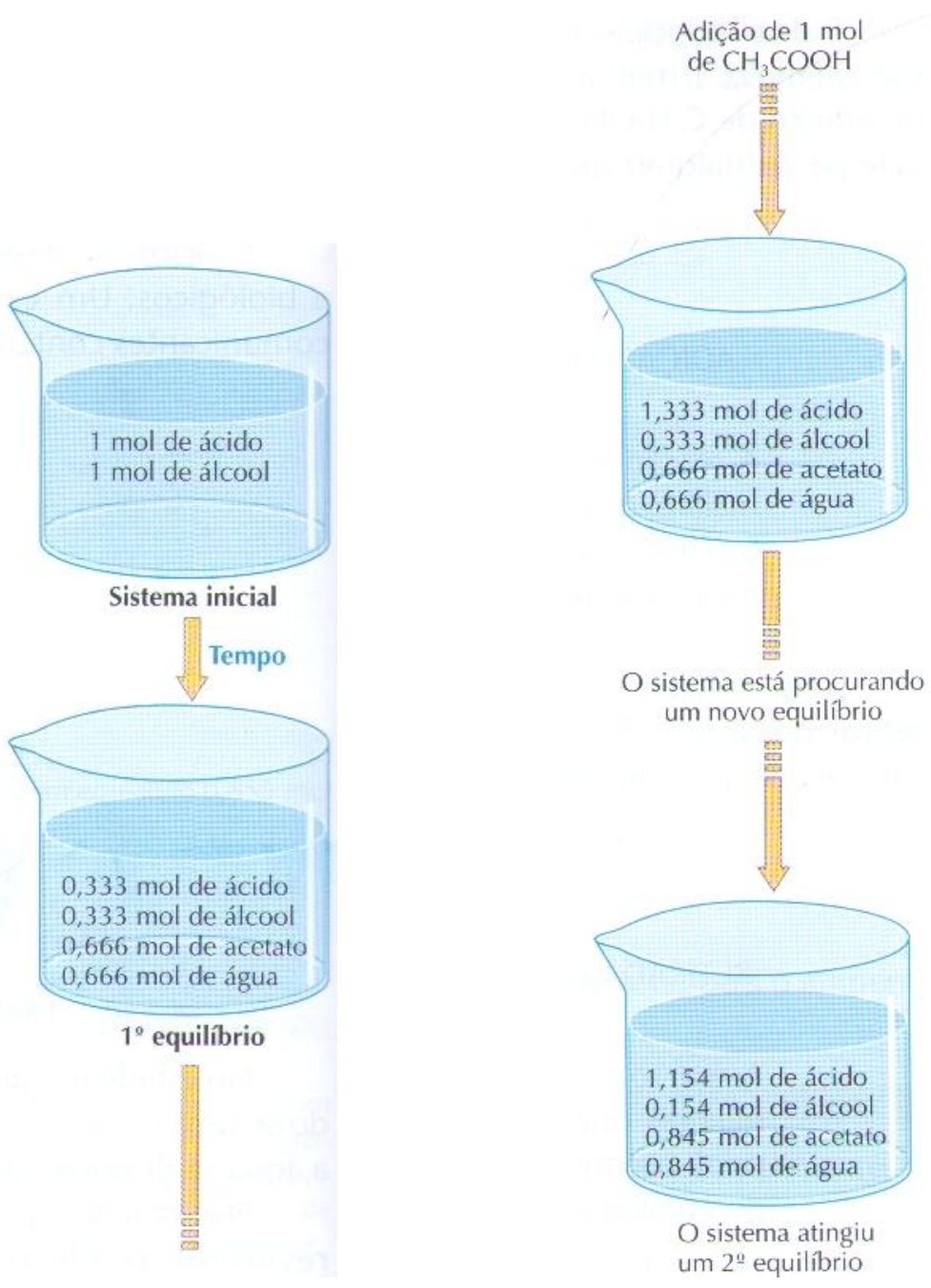

Figura 5: ilustração retirada do livro RF que representa o nível macroscópico e indica as quantidades em mol dos participantes em diferentes estágios da evolução do equilíbrio. 
Porém, neste exemplo (uma reação de esterificação) não há evidências macroscópicas da ocorrência de uma reação química, que neste caso então, é evidenciada pela variação das quantidades dos constituintes no decorrer do tempo.

Uma observação pertinente refere-se ao livro TC, no capítulo de introdução aos equilibrios químicos. Ao estudar o equilíbrio gasoso $\mathrm{N}_{2} \mathrm{O}_{4} \rightleftarrows \mathrm{NO}_{2}$, este livro inclui desenhos de balões volumétricos na parte superior do gráfico (nível macroscópico) com a respectiva coloração no decorrer do tempo até o sistema atingir o estado de equilíbrio químico.

Porém, no capítulo seguinte que trata as alterações de equilíbrios, em que o mesmo sistema sofre uma modificação, o desenho destes balões acompanhando o gráfico, que mostra a mudança de concentração ao longo do tempo, não é apresentado. Segundo Milagres e Justi (2001) as associações de desenhos com gráficos deveriam ser mais utilizadas por autores de livros didáticos com o objetivo de integrar as ideias entre os níveis abordados no triângulo de Johnstone ao estudar os efeitos das mudanças de concentração.

Dentre os equilibrios químicos mais comuns para o estudo do efeito da concentração presentes nos livros didáticos está o equilibrio dicromato-cromato: livros VN e US (figura 6) quando se altera a concentração em meio ácido e/ou alcalino.

Outra ilustração, encontrada no livro TC, estuda a variação da concentração através do equilíbrio entre o cloreto de cobalto II e seu ín complexo.

Um último equilíbrio a se considerar está presente no livro PEQUIS, cuja ilustração retrata o equilíbrio do ácido carbônico em água em presença do indicador ácido-base chamado fenolftaleína.

Estes equilibrios, por apresentarem dois recipientes diferentes e com colorações distintas não deixam evidente ao aluno, em aspectos visuais, a coexistência de reagentes e produtos em ambos os frascos representados.

Além disto, foram analisadas se estas figuras que tratam de sistemas macroscópicos estão relacionadas aos outros dois níveis do triângulo de Johstonne (microscópico e representacional). Nenhuma das figuras macroscópicas encontradas faz menção ao respectivo nível microscópico.

Com relação ao nível representacional, podemos citar duas características: a presença da equação química referida ao equilibrio em questão e a inclusão de 
fórmulas contidas nos recipientes macroscópicos das figuras, como visualizado na figura 6.
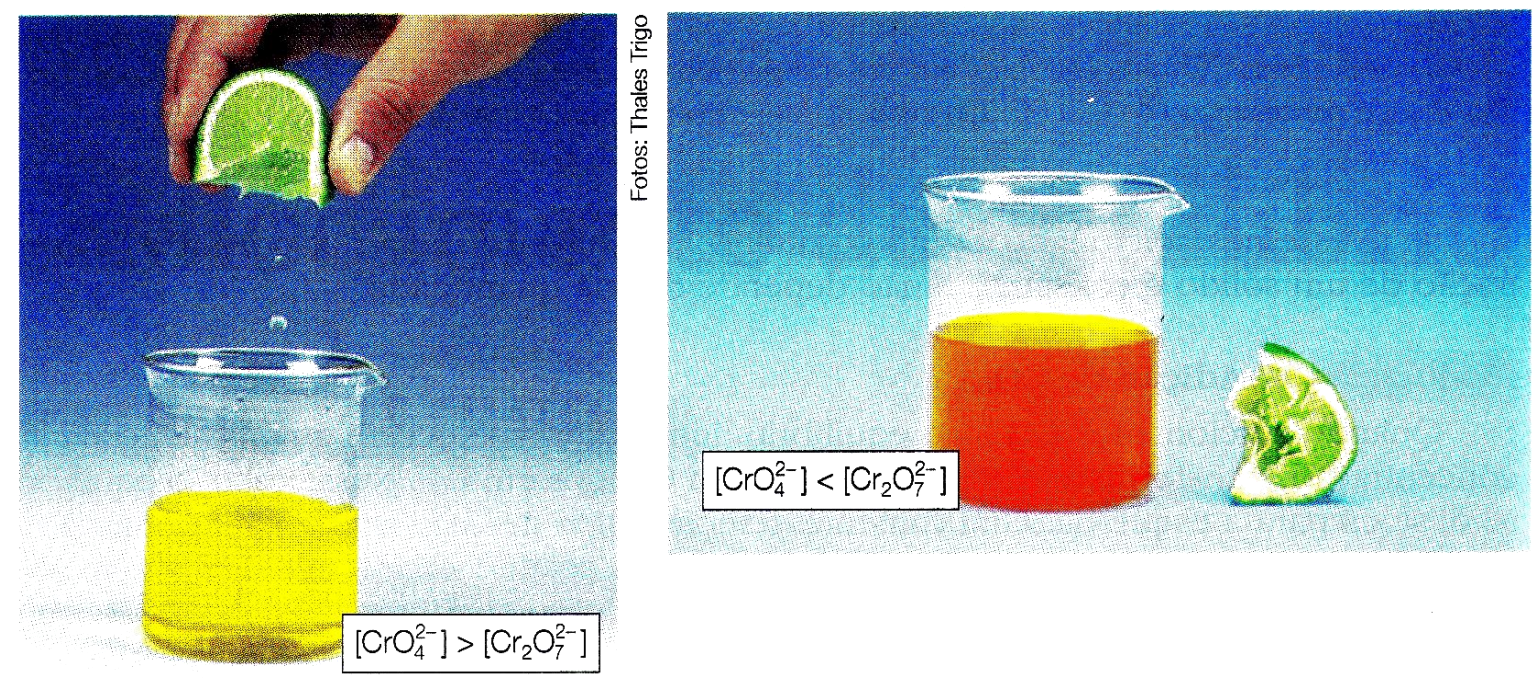

Figura 6: figura retirada do livro US que apresenta o nível repres entacional nas concentrações

Percebe-se o cuidado da maioria dos livros em apresentar a equação química do equilibrio químico representado na figura em questão, mas o mesmo não ocorre com a representação das fórmulas associadas dos desenhos, ou seja, poucos são aqueles que apresentam a fórmula associada à figura, descaracterizando uma possível interligação prevista pelo triângulo de Johnstone.

A única figura microscópica que mostra o estudo sobre os efeitos da concentração foi encontrada no livro VN (figura 3), cuja discussão foi apresentada na página 45.

\subsubsection{A variação de temperatura}

A análise do fator temperatura é abordada semelhantemente em todos os livros didáticos, que mencionam que o aumento ou diminuição de temperatura irá favorecer o sentido da reação endotérmica (absorção de calor) ou exotérmica (liberação de calor), respectivamente. Em contrapartida, um aspecto fundamental durante a discussão sobre alteração de temperatura, o que diz respeito à variação 
da constante de equilíbrio com a mesma, não é mencionada textualmente em três livros didáticos (PEQUIS, SF, MM) quando estes discutem alterações no estado de equilibrio químico. É importante ressaltar que dois destes livros pertencem a importantes grupos de pesquisa em ensino de química.

Trata-se de um aspecto fundamental pois dentre os principais problemas detectados no aprendizado do tema equilíbrio químico estão a dificuldade que muitos alunos apresentam em aplicar o princípio de Le Chatelier diante de mudanças de temperatura e o desconhecimento de que o valor da constante de equili ibrio (K) varia com a temperatura (RAV IOLO E MARTINEZ-AZNAR, 2003).

Alguns autores têm apontado a necessidade de, no processo de ensino, especificar claramente que mudanças de temperatura afetam o valor da constante de equilíbrio (CAMACHO E GOOD, 1989) além de se enfatizar o papel da variação de entalpia da reação (VOSKA E HEIKKINEN, 2000). Os demais livros mostram a variação da constante de equilíbrio com a temperatura apresentando exemplos empíricos por meio de tabelas que relacionam, para uma mesma transformação química, diferentes temperaturas em que o experimento é realizado e os respectivos valores de constante de equilíbrio (VN, TC, GEPEQ, RF e US) ou ainda na forma de gráficos (TC, RF e US), em que o sentido do gráfico é diretamente relacionado à variação de entalpia da reação.

Esta abordagem é útil, justamente, porque mostra de maneira explícita como $\mathrm{K}$ pode variar com a temperatura, além de ser uma maneira interessante de se introduzir a regra de Van't Hoff, quer seja esta expressa na forma de um enunciado qualitativo (DE HEER,1957) ou quantitativo, expresso por meio de uma equação matemática como foi proposto por Cheung (2004) e discutido anteriormente.

Vale lembrar que, além da dependência da constante de equilíbrio com a temperatura para equilíbrios iônicos em solução aquosa, esta depende também da força iônica da solução, ou seja, da concentração total de íons presentes na solução (SKOOG et al., 2006).

Com relação à análise das ilustrações, apenas três dos sete livros (RF, US e TC) apresentam gráficos sobre a alteração da temperatura relacionada com a constante de equilíbrio, e outros dois (GEPEQ e VN) mostram esta variação através de apresentação de tabelas. Quílez (1997) realiza um estudo e constata que grande porcentagem dos alunos não relaciona a mudança da temperatura com a constante de equilíbrio $\left(\mathrm{K}_{\mathrm{c}}\right)$. 
De modo geral, verifica-se experimentalmente que:

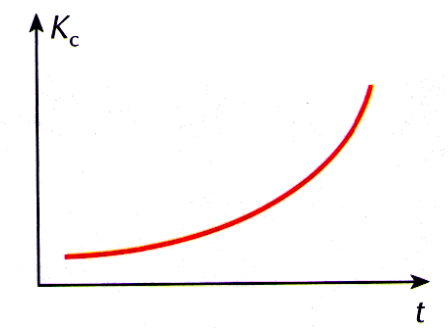

Nas reações endotérmicas o valor de $K_{\mathrm{c}}$ aumenta com a temperatura.

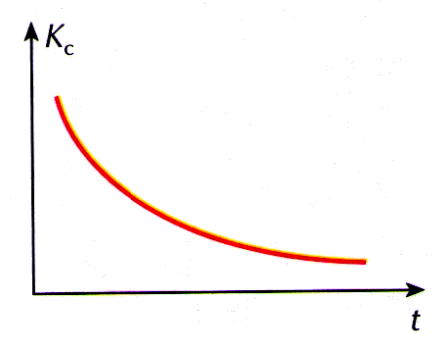

Nas reações exotérmicas o valor de $K_{\mathrm{c}}$ diminui com a temperatura.

Figura 7: gráfico que mostra a variação da constante de equilíbrio com a temperatura (livro RF)

Portanto, a utilização deste recurso gráfico (ou tabela), presente na figura 7, auxilia o estudante a perceber como uma reação endotérmica ou exotérmica se comporta a uma alteração na temperatura, fato que não foi constatado nos livros MM, SF e PEQUIS.

Em contrapartida, um único livro $(\mathrm{RF})$ também mostra graficamente como a porcentagem dos componentes do equilíbrio se modifica ao se alterar a temperatura, e o livro GEPEQ se utiliza de uma tabela para ilustrar este aspecto.

O livro TC, ao discutir a mudança de temperatura, mostra uma figura que favorece o entendimento da coexistência de reagentes e produtos em um equilíbrio químico, e é o único que retrata três momentos deste sistema: um balão com a mistura em temperatura ambiente, outro imerso em um banho de água com gelo e um terceiro balão mergulhado em água fervente (figura 8).

Este aspecto é considerado positivo pois uma das dificuldades encontradas pelos alunos é capacidade de verificação da coexistência de reagentes e produtos em um equilíbrio químico (QUíLEZ, 1995).

A alternância da coloração nestas três temperaturas distintas em um mesmo recipiente (equilíbrio $\mathrm{N}_{2} \mathrm{O}_{4} \rightleftarrows \mathrm{NO}_{2}$ ) ao invés de dois frascos distintos, como 0 representado na figura 4 , pode minimizar a formação de outra possível concepção alternativa presente em muitos estudantes, a chamada "compartimentalização do equilibrio químico", em que os alunos tendem a considerar que os reagentes e produtos do sistema estão em compartimentos separados (QUÍLEZ, 1998; RAVIOLO E AZNAR, 2003). 


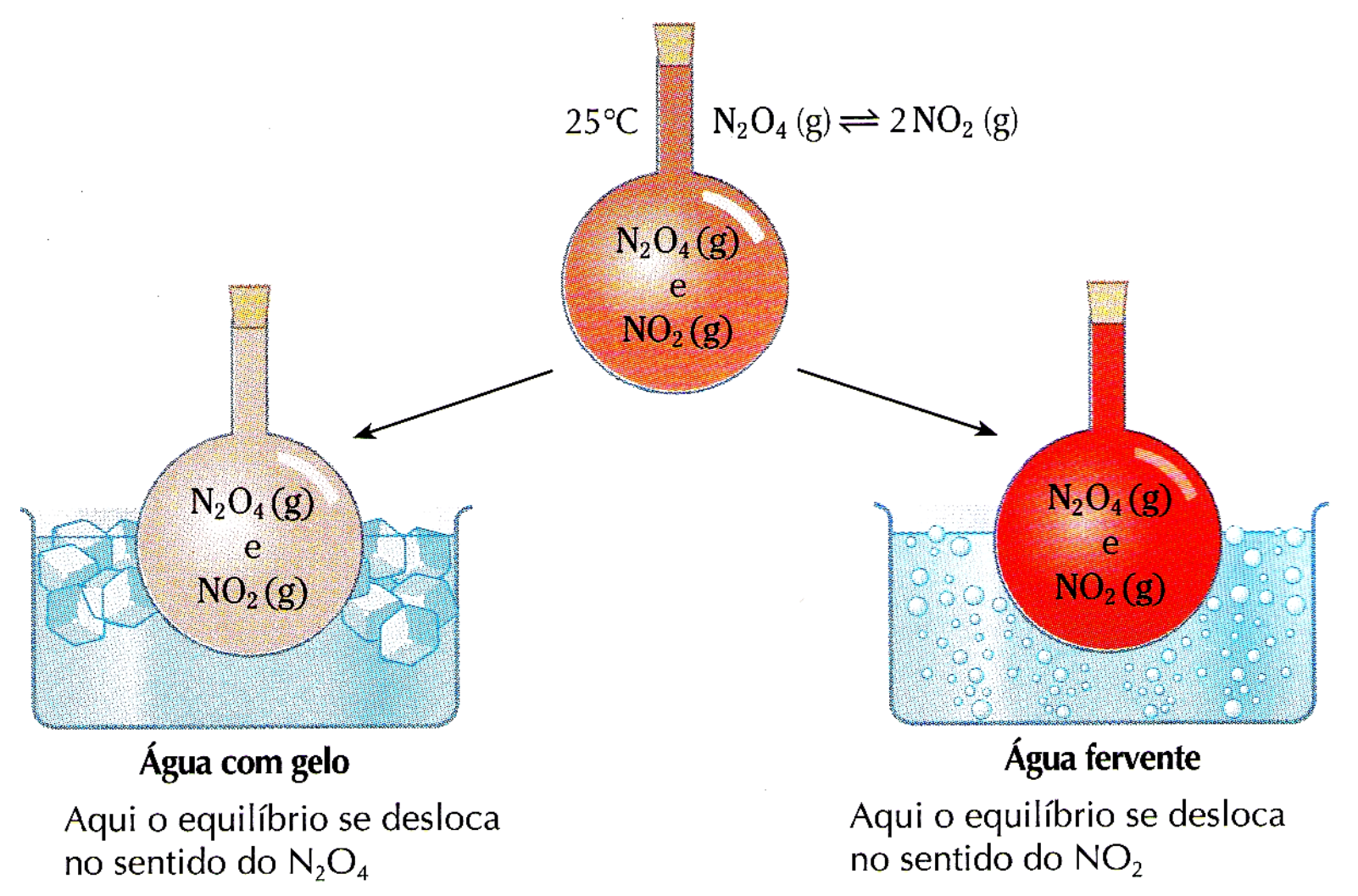

Figura 8: alteração de temperatura de um sistema real acompanhado da simbologia química (livro TC)

\subsubsection{A utilização de catalisador}

A influência do uso de catalisador em equilibrios químicos é abordada por seis livros e dentre estes, três (SF, VN, GEPEQ) apenas mencionam o fato de o catalisador não afetar o equilíbrio e explicam este fato textualmente: "aumenta somente as velocidades dos processos: direto e inverso" (VN, p.400) ou "diminui a energia de ativação e aumenta a velocidade de modo igual para as duas reações (direta e inversa)" (SF, p.314). No livro GEPEQ é dito: "Quanto ao catalisador, podese concluir que ele não afeta o equilibrio, pois acelera ao mesmo tempo ambas as transformações (direta e inversa). O papel do catalisador é fazer com que o estado de equilíbrio seja atingido mais rapidamente." (GEPEQ, p.137). 


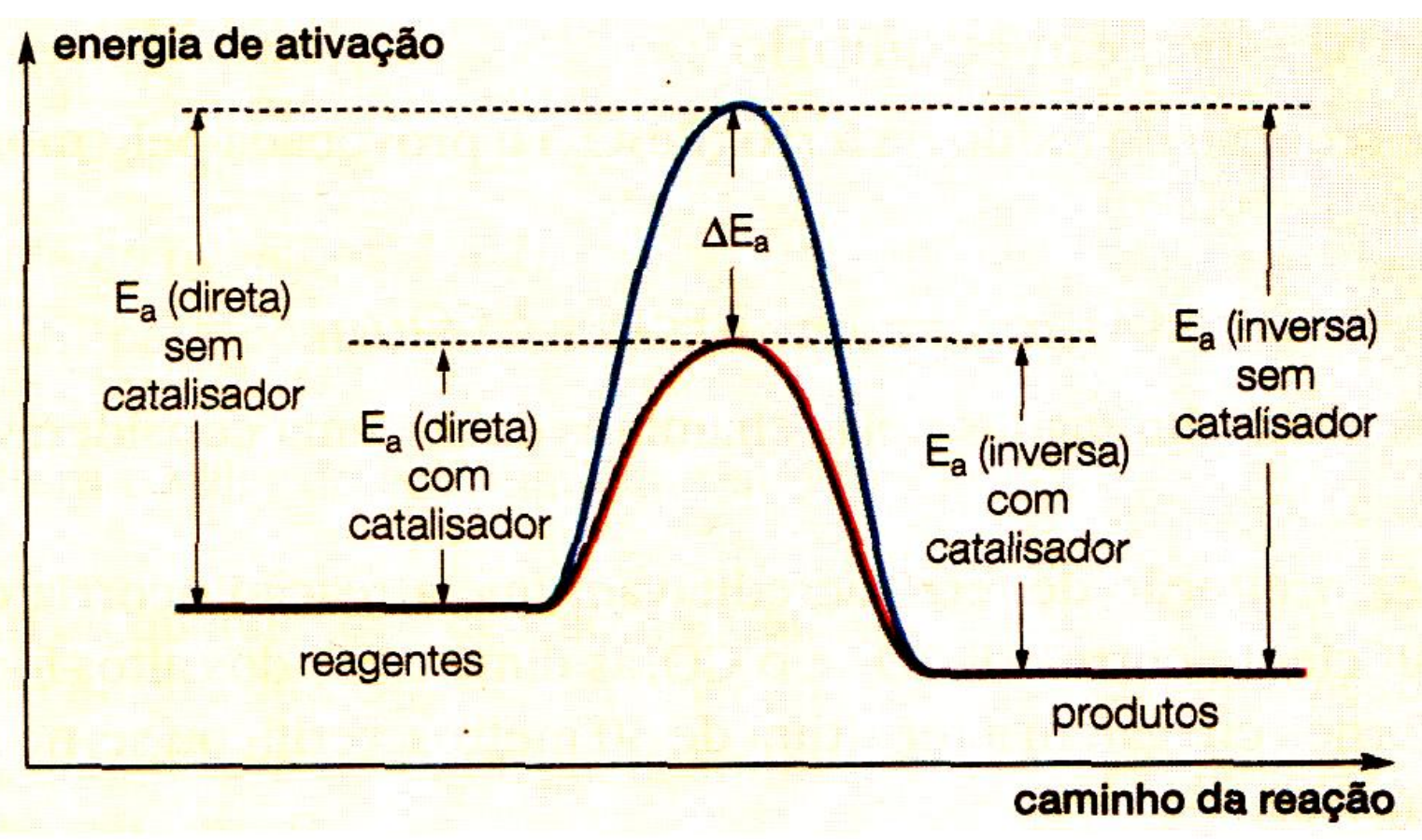

Figura 9: Gráfico da energia de ativação versus caminho da reação (livro US)

Outros três (US, RF, TC) tratam o tema em um subtítulo com destaque igual ao das demais variáveis. Explicam que o catalisador diminui igualmente 0 valor a energia de ativação tanto da reação direta como da reação inversa e ilustram este fato com o gráfico de energia de ativação versus caminho da reação (figura 9).

Este tipo de representação gráfica pode auxiliar a evitar a concepção alternativa, normalmente encontrada, de que o catalisador favorece a formação de produtos (RAVIOLO E MARTíNEZ-AZNAR, 2003) uma vez que, sem a familiaridade com os aspectos dinâmicos e reversíveis do equilibrio, muitos alunos tendem a considerar o efeito do catalisador apenas no aumento da velocidade da reação direta.

Outro gráfico presente nestes três últimos livros mencionados (US, RF, TC) relaciona a concentração de reagentes e produtos em função do tempo, tanto na presença e como na ausência de catalisador (figura 10).

Este segundo gráfico evidencia de maneira clara que 0 valor das concentrações de reagentes e produtos quando atingido o equilíbrio químico, isto é, quando as concentrações são constantes em função do tempo, não são diferentes com ou sem a adição de um catalisador. Portanto, o que se altera é apenas o tempo necessário para se atingir o estado de equilíbrio químico. Um dos livros (TC) ainda mostra outra figura que compara os gráficos de concentração dos reagentes e 
produtos em função do tempo para a reação $\mathrm{N}_{2} \mathrm{O}_{4(\mathrm{~g})} \rightleftarrows 2 \mathrm{NO}_{2(\mathrm{~g})}$ na presença e ausência de catalisador com o gráfico para a reação na ausência de catalisador, mas a uma temperatura maior, cuja a formação de $\mathrm{NO}_{2}$ é favorecida.

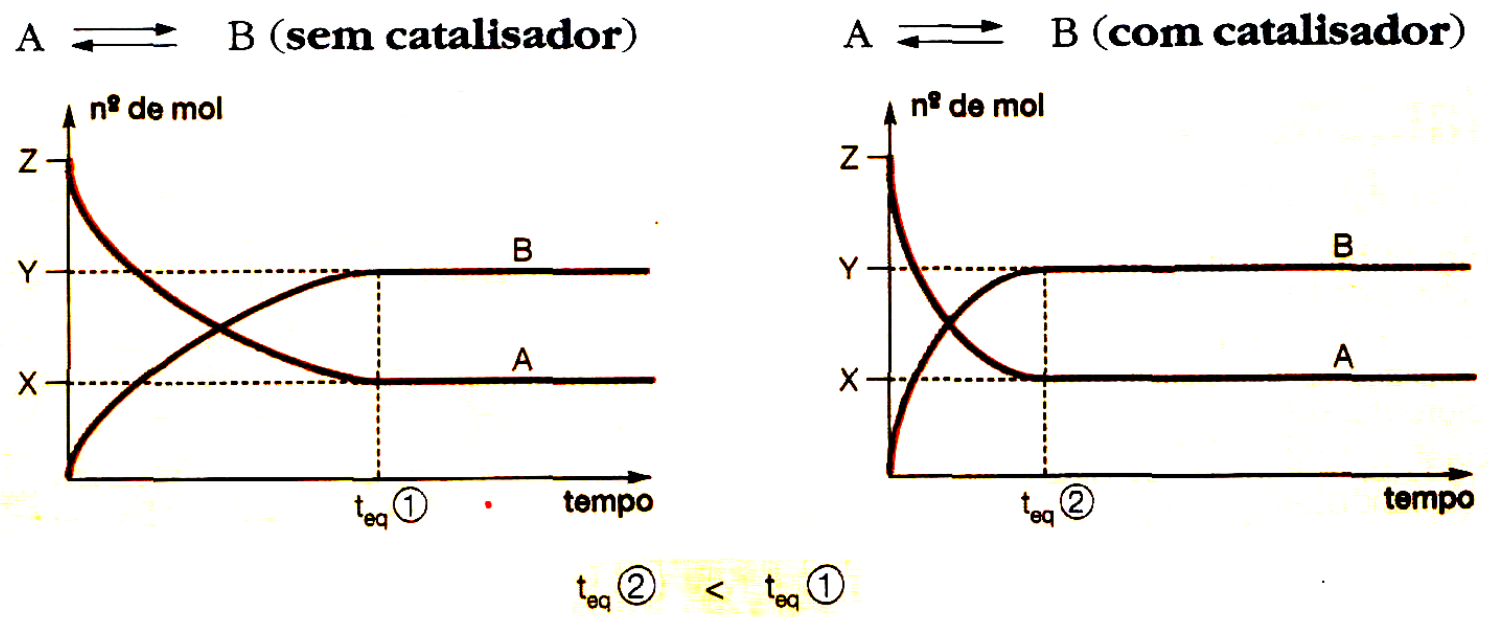

Figura 10: Gráfico que ilustra equilíbrios na ausência e presença de catalisador (livro US)

Neste caso o aluno pode verificar graficamente quais são as condições que promovem ou não alterações no estado de equilíbrio através da comparação das concentrações finais de reagentes e produtos, ao se atingir o estado de equilibrio químico. Seria interessante também que, ao abordar estes gráficos, fosse apresentada a equação da constante de equilíbrio, de maneira que o aluno perceba que a adição de um catalisador não afeta o valor de $\mathrm{K}_{\mathrm{c}}$, enquanto que um aumento de temperatura o altera.

Isto pode contribuir em muito para que os alunos tenham a correta concepção do significado da expressão matemática de $\mathrm{K}_{\mathrm{c}}$ e em que condições seu valor é ou não modificado. No entanto, em nenhum dos livros didáticos é feita esta comparação para o caso da adição de um catalisador.

De qualquer forma, representações gráficas deste tipo devem ser incentivadas, já que ajudam a revelar importantes aspectos relacionados à natureza do equilíbrio químico (RAVIOLO E MARTíNEZ-AZNAR, 2003).

\subsubsection{A influência da pressão}

Com relação à variável pressão em equilíbrios homogêneos gasosos, em todos os livros é abordado, de maneira explícita ou implícita, o caso do aumento ou 
diminuição da pressão que ocorre através da variação do volume total do sistema (caso de um reator formado por um pistão ou um êmbolo móvel).

Neste exemplo, a aplicação literal do princípio de Le Chatelier funciona sem nenhum tipo de problema. Somente dois livros (MM e SF) não fazem referência explícita a um reator deste tipo, embora todo o tratamento realizado considere implicitamente a relação entre a variação de pressão-volume.

Os livros SF, TC e VN tratam apenas da variação pressão-volume apresentando explicitamente uma figura de um reator com êmbolo móvel. Em dois livros (RF e PEQUIS), a variação de pressão é discutida de uma maneira geral e somente ao final da explicação é apresentado um exemplo ilustrado através de uma figura deste tipo, evidenciando ser este o caso em questão.

O livro GEPEQ (figura 11) também trata principalmente do caso da variação pressão-volume, mas afirma:

Mudanças de pressão podem ser conseguidas de várias maneiras. Assim, por exemplo, pode-se aumentar a pressão introduzindo-se no sistema em equilíbrio maior quantidade (maior quantidade de partículas) de algum componente gasoso. Neste caso, como a pressão de um gás é proporcional à sua concentração $(p=n R T / V)$ e, portanto, ao número de partículas, o aumento destas implica no aumento da pressão total. O efeito será semelhante ao do aumento da concentração de um componente em solução. (GEPEQ, p.130 131).

Neste caso está implícito, e talvez o aluno não perceba que esta adição acontece a volume constante.

Percebe-se, na análise da figura 11, que a mesma apresenta uma junção das representações macro e microscópicas abordadas pelo triângulo de Johnstone. Os livros US e VN ilustram este mesmo exemplo. Todas estas figuras representam a variação de pressão utilizando-se do modelo de um pistão (macroscópico) contendo um modelo de partículas dentro dele (microscópico).

A mistura dos níveis macroscópico e microscópico, relacionada ao triângulo de Johnstone, aparece em uma discussão no estudo de Milagres e Justi (2001), que destacam as dificuldades que os alunos podem apresentar ao se misturar estes dois níveis de representação. 


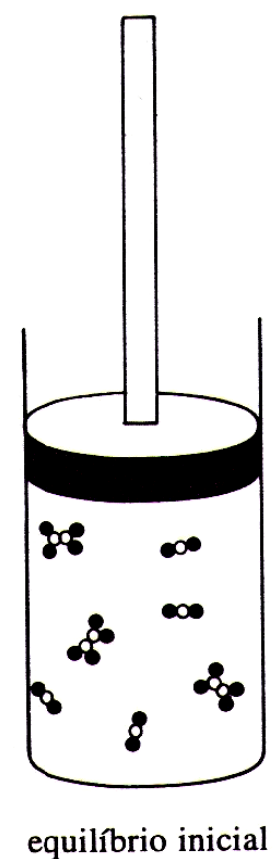

(I)

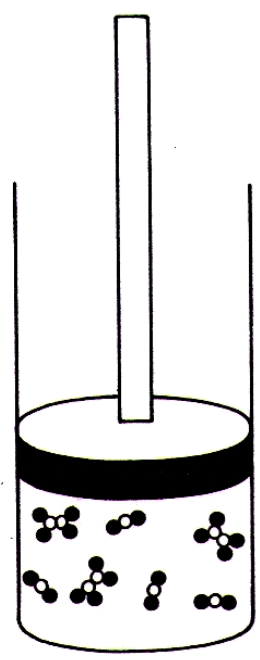

(II)

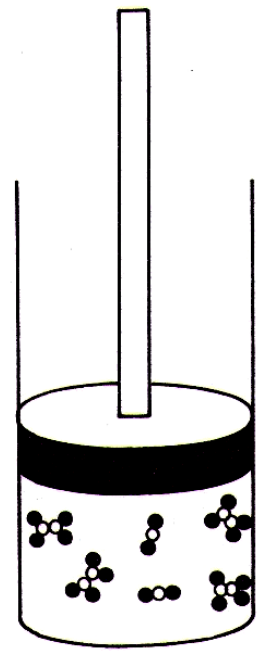

(III)

Figura 11: ilustração do livro GEPEQ que mistura os níveis macro e microscópico

Os autores destacam que os estudantes podem se confundir com as partículas "flutuando" em um pistão macroscópico e gerar dúvidas do que seriam estes espaços vazios entre as partículas, o meio macroscópico ou ausência de matéria. Além disto, o trabalho ressalta a importância da proporcionalidade entre o tamanho do pistão e das partículas, aspecto que pode causar confusão entre os alunos. Sendo assim, acabam concluindo:

Qualquer que seja o caso, o comprometimento do entendimento de questões tão básicas da química não justifica a apresentação de desenhos nos quais os dois níveis são representados simultaneamente. (Milagres e Justi, 2001)

Com o objetivo de se evitar os possíveis problemas apontados anteriormente, uma alternativa interessante seria apresentar o desmembramento da figura 10, que contém os dois níveis simultâneos, em duas ilustrações independentes e distintas. A primeira poderia representar o modelo de pistão (macroscópico), a variação do volume com a pressão e uma possível coloração do sistema, conforme o exemplo de equilibrio químico escolhido. E a segunda, 
relacionada à primeira, mostraria as partículas dispostas em um determi nado espaço definido, tal como aquele presente na figura 3.

Esta alternativa está presente em ilustrações presentes nos livros TC, GEPEQ (outra ilustração) e RF. Nestas figuras, o exemplo do "pistão móvel" não contém modelos de partículas inseridos neles, e estes livros apresentam outra ilustração contendo o nível macroscópico e, nos exemplos selecionados, o estudante consegue perceber a mudança da pressão total por meio da alteração da coloração do sistema.

No exemplo contido no livro GEPEQ, a ilustração mostra três desenhos destacando distintos valores de pressão e volume, para um determinado equilîbrio genérico. Esta figura apresenta diferenças de tonalidade, porém, como a impressão do livro didático está em preto e branco, o leitor não consegue distinguir as cores destas três etapas, caso seja este um equilibrio que apresente alguma coloração característica.

Em contrapartida, os livros TC e RF escolhem 0 equilibrio $\mathrm{N}_{2} \mathrm{O}_{4(\mathrm{~g})} \rightleftarrows 2 \mathrm{NO}_{2(\mathrm{~g})}$ como exemplo para este modelo. Ao se tratar de um equilíbrio real, ambos os livros preocupam-se em apresentar o nível representacional do triângulo de Johnstone com a inclusão de fórmulas nos desenhos dos êmbolos móveis. É importante destacar que as figuras apresentam coloração característica, como encontrado na figura 12 do livro RF.

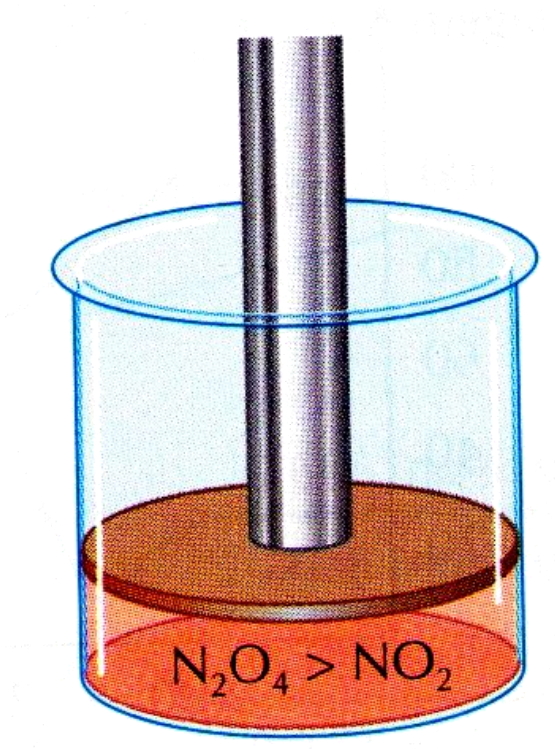

Estado inicial

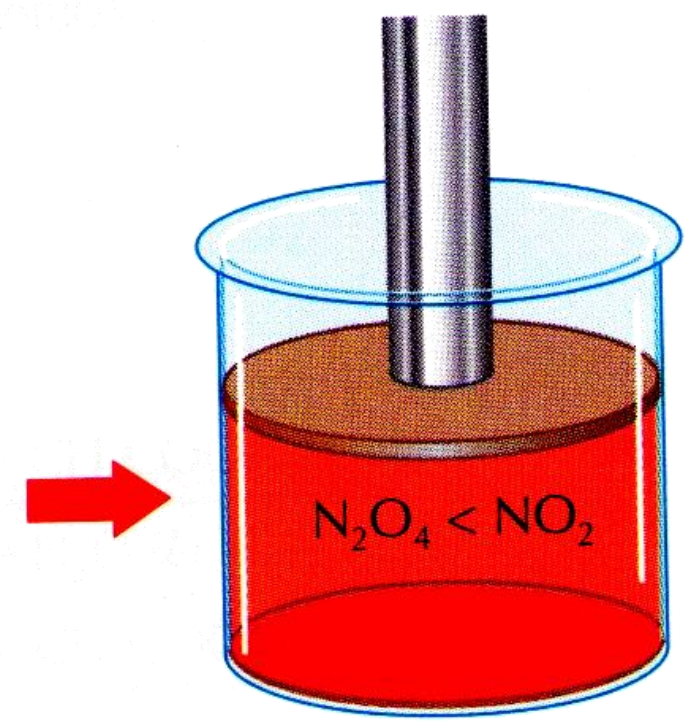

Estado final

Figura 12: ilustração que contém o nível macroscópico e representacional sobre a mudança da pressão-volume em um êmbolo móvel (livro RF) 
Porém, no caso do livro TC, a impressão da ilustração prejudica a percepção da diferença de tonalidade de coloração entre as duas figuras que apresentam pressões distintas. De forma análoga à temperatura, o livro RF é o único a expressar através de um gráfico como o equilỉbrio responde à variação da pressão do sistema. Este gráfico está associado a uma tabela, que mostra diferentes valores de pressão e as respectivas porcentagens de amônia obtida (produto).

Em apenas dois livros (US e RF) é abordado o caso do aumento de pressão devido à adição de um gás inerte, exemplo este, em que a aplicação do princípio de Le Chatelier pode levar a previsões equivocadas (Katz, 1961). O tema é abordado nestes livros através de uma pequena nota, chamada de observação, logo após a explicação sobre a influência da pressão. No caso do livro US, segue o trecho transcrito a seguir:

Se adicionarmos gás inerte a um sistema em equilibrio, ocorre um aumento da pressão total do sistema. No entanto, como não há variação da concentração nem das pressões parciais de cada gás componente do equilíbrio, a adição de gás inerte não afeta o equilíbrio. (US, p.372).

Palavras semelhantes são usadas no livro RF, embora este último não faça referência às pressões parciais ou às concentrações, é o único que ressalta que isto vale para "uma reação que se processa sem variação de volume" (RF, p.205).

É importante destacar que isto é verdadeiro apenas para a adição de um gás inerte a volume constante.

Em todos os casos são apresentadas conclusões a respeito da variação pressão-volume na forma de regras qualitativas do tipo: "o aumento da pressão total desloca o equilíbrio para o lado do volume menor (ou seja, da menor quantidade total de mols)" (RF, p.205). Apenas o livro TC faz referência à equação matemática de $K_{c}$, como prova de uma afirmação deste tipo.

Neste último exemplo, a equação $K c=\left(n_{\mathrm{NO}_{2}}^{2} / n_{\mathrm{N} 2 \mathrm{O} 4}\right) \cdot 1 / V$, permite ilustrar melhor as relações envolvidas entre as diferentes variáveis, uma vez que um aumento de pressão (diminuição de V) exige que o quociente $\left(n_{N O 2}{ }^{2} / n_{N 2 O 4}\right)$ diminua para que o valor de $K c$ se mantenha constante. 
É justamente este o tipo de abordagem que a literatura tem indicado como alternativa viável ao uso exclusivo do Princípio de Le Chatelier (KATZ, 1961; CHEUNG, 2004 e 2009).

\subsection{Considerações sobre a totalidade das ilustrações}

Uma análise geral das ilustrações presentes nos livros didáticos, tomando-se como referência a interligação entre os vértices do triângulo de Johnstone, mostrou que a maioria das ilustrações $(38 \%)$ analisadas pertence ao universo mais próximo ao aluno, ou seja, o nível macroscópico.

Destas 15 ilustrações, percebe-se que todas procuram explorar exemplos que mostrem a mudança de cor ao se alterar o estado de equilibrio químico. Todos os livros que apresentaram ilustrações ao longo deste capítulo continham pelo menos uma figura de um sistema real (macroscópico).

Deste modo, foram encontrados os seguintes equilíbrios químicos: dicromato-cromato (cores amarelo e laranja), $\mathrm{N}_{2} \mathrm{O}_{4(\mathrm{~g})} \rightleftarrows 2 \mathrm{NO}_{2(\mathrm{~g})}$ (mistura de gases incolor e castanho), cloreto de cobalto II e seu íon complexo (cores azul e rosa) e apenas uma única figura sobre o equilibrio do ácido carbônico em água em presença de fenolftaleína (aspecto incolor e coloração rósea).

O equilíbrio $\mathrm{N}_{2} \mathrm{O}_{4(\mathrm{~g})} \rightleftarrows 2 \mathrm{NO}_{2(\mathrm{~g})}$ foi o preferido da maioria dos autores e esteve presente em 8 ilustrações. Dentre estas, a maioria preferiu mostrar dois momentos em que foi alterada a temperatura (PEQUIS, VN e TC) ou a pressão (PEQUIS, RF e TC). Apenas em uma destas figuras (livro TC), na discussão da variável pressão, a mudança de coloração do sistema não é perceptível na ilustração apresentada. Para esta última variável, é importante frisar que a maioria dos livros didáticos refere-se ao modelo de um gás presente em um pistão de êmbolo móvel.

A análise do total de gráficos (18) mostrou que todos estes são acompanhados da respectiva simbologia química (nível representacional) e nenhum faz menção ao nível molecular. Apenas o livro RF apresenta uma figura macroscópica associada a um gráfico. 
A minoria das ilustrações encontradas nos livros didáticos (15\% do total) ilustra o universo microscópico de átomos e moléculas. Somente os livros VN, PEQUIS e GEPEQ (uma figura cada) apresentam ilustrações exclusivas ao nível microscópico, como exemplificado na figura 3.

Portanto, podemos concluir que a maioria dos livros tem o cuidado em representar a equação química do equilibrio ilustrado na figura, pois, apenas o livro PEQUIS não apresenta a equação $\mathrm{N}_{2} \mathrm{O}_{4(\mathrm{~g})} \gtrless 2 \mathrm{NO}_{2(\mathrm{~g})}$ quando discute a variação de temperatura para este sistema. E, da mesma maneira que as figuras macroscópicas não estão associadas às microscópicas, estas também não se referenciam a nenhum sistema macroscópico.

\subsection{Quais limitações do princípio são discutidas?}

Foi analisado, também, se são apresentadas algumas das limitações à aplicação literal do Princípio de Le Chatelier através de exemplos específicos ou de casos mais gerais (KATZ,1961). Nenhum dos livros afirma, no momento exato em que apresenta o princípio, que o mesmo não deve ser aplicado diretamente em determinadas situações, ou que podem existir determinadas condições onde esta generalização não é válida, muito menos apresenta exemplos como anteriormente citados.

Apenas em um dos livros (RF) é dito claramente, em um capítulo posterior, onde são discutidos equilíbrios heterogêneos que existem limitações na aplicação do princípio de Le Chatelier. No entanto, parece deixar a impressão de que estas limitações não abalam o "status" do princípio. A transcrição desta observação é a seguinte: "O Princípio de Le Chatelier, visto na página 202, continua valendo para os equilibrios heterogêneos, embora com certas ressalvas, que discutiremos a seguir" (RF, p.262). Ao analisar o caso de um equilíbrio químico heterogêneo envolvendo gases e, tendo em vista que a pressão tem uma influência desprezível sobre sólidos e líquidos afirma: "ao aplicar o princípio de Le Chatelier em um sistema heterogêneo, devemos considerar apenas a presença das substâncias gasosas, empregando então o que foi visto à página 205" (RF, p.263). A seguir, afirma diretamente que a 
adição ou remoção de um sólido que participa de um equilíbrio químico não altera o mesmo.

Outro livro (TC) ao discutir equilíbrios heterogêneos gasosos envolvendo a presença de sólidos diz: "No capítulo 27 discutimos o princípio que rege os deslocamentos de equilíbrio, chamado Princípio de Le Chatelier. Vamos agora discutir sua aplicação aos sistemas heterogêneos." (TC, p.533). Em seguida os autores concluem que "a adição ou retirada de participante sólido não desloca um equilîbrio" uma vez que a adição de um sólido "não altera sua concentração em mol/L [...] e assim o equilíbrio não é deslocado." (TC, p.533). Com esta abordagem, o princípio de Le Chatelier consegue justificar que a adição de um sólido não afeta um equilíbrio heterogêneo já que a "concentração" do sólido não é afetada. O livro US também explica que "a concentração de um sólido é constante e não depende de sua quantidade" (US, p.369) e afirma, ao discutir a variação de pressão em equilibrios heterogêneos, que "as concentrações molares dos sólidos... não são afetadas por variações de pressão por serem incompressíveis." (US, p.371). Outro autor (SF) não discute extensivamente o caso de um equilibbrio heterogêneo gasoso, mas simplesmente afirma em um quadro de observações que a "adição ou remoção de uma parcela de uma espécie sólida... não provoca deslocamento" (SF, p.314), sem diferenciar claramente no texto os equilíbrios homogêneos de heterogêneos.

Quanto à adição de um sólido em equilíbrios de solubilidade, apesar de alguns livros apresentarem um capítulo ou subtítulo sobre o tema (VN, TC, RF, US e SF), em nenhum deles é tratado o caso da adição de uma maior quantidade de sólido. No livro VN, o único equilíbrio heterogêneo formalmente apresentado no te xto é o caso do equilíbrio de solubilidade. Neste caso, também não é apresentado o fato de que a adição ou remoção de um sólido não afeta o estado de equilíbrio. No entanto, a autora afirma, ao definir $K_{P S}$, que não faz sentido falar em concentração de sólido "que está no fundo do recipiente, uma vez que ele sequer está em solução [...]". (VN, p.412).

Concluindo, metade dos livros (SF, TC, RF, US) menciona, de alguma forma que a adição de um sólido não influencia um equilíbrio químico heterogêneo. Os demais livros (VN, PEQUIS, GEPEQ e MM) não dão ênfase em alterações envolvidas nos equilíbrios em sistemas heterogêneos, embora os mesmos possam aparecer em problemas ou exercícios. A correta compreensão dos fenômenos envolvidos nos equilíbrios heterogêneos implica também em conhecer o conceito de 
fase e o fato de que neste tipo de equilíbrio há troca de material entre duas fases em contato. Isto deve levar o aluno a perceber que não importa, por exemplo, a quantidade de sólido presente no sistema (gramas ou quilogramas), mas que é imprescindível a presença deste sólido como uma das fases. Outro aspecto fundamental a ser compreendido é de que a quantidade de sólido (expressa em massa ou em quantidade de matéria) presente em uma unidade de volume é constante, ou seja, sua "concentração" não se altera e este valor está embutido na constante de equilíbrio (SKOOG et al., 2006).

De uma forma mais rigorosa devem ser utilizadas as atividades químicas dos componentes em equilibrio no cálculo de $K$ sendo que, para um componente puro no seu estado padrão, é atribuído como valor de atividade química igual à unidade. Como a atividade de sólidos e líquidos é pouco sensível à variação de pressão, considera-se que, em pressões moderadas (menores do que 20 bar), seu valor seja também igual à unidade (LEVINE, 1988 p. 304). No entanto, como o conceito de atividade não é tratado no ensino médio, costuma-se justificar a ausência da substância pura na equação matemática de $\mathrm{K}$ devido à constância de sua concentração. Embora largamente utilizado, em nossa opinião, pode-se questionar se faz sentido utilizar o conceito de concentração para substâncias puras, uma vez que o mesmo é definido para soluções (misturas homogêneas) como a razão entre uma quantidade de um soluto e o volume da solução (Quílez-Pardo, 1998). Uma questão que pode ser colocada é se esta possível ambigüidade pode induzir o aluno a confundir, por exemplo, os conceitos de concentração e densidade. De qualquer forma deve ficar claro para o aluno que sólidos e líquidos puros não fazem parte da expressão da constante de equilíbrio $(K)$.

Assim, generalizando, sólidos e líquidos puros não fazem parte da expressão de $\mathrm{K}$ e deve-se considerar que mudanças nas massas de líquidos ou sólidos puros não afetam o estado de equilíbrio (SOLAZ-PORTOLES E QUÍLEZPARDO, 2001). Particularmente no caso dos equilíbrios de solubilidade de sólidos iônicos, é importante lembrar que o valor do produto de solubilidade $\left(K_{P S}\right)$ é dependente da temperatura e da força iônica da solução, que está relacionada com concentração de outros possíveis íons presentes e que não façam parte do equilíbrio de solubilidade em questão (SKOOG et al., 2006). Embora o conceito de força iônica não seja tratado no ensino médio é fundamental ter-se em conta este fato, muitas vezes esquecido ou negligenciado. 
Nos casos de equilíbrios heterogêneos, a solução correta é a utilização da expressão da constante de equilíbrio, ou seja, a comparação do valor do quociente de reação $(Q)$, após a alteração promovida no sistema em equilíbrio, com o valor da constante de equilîbrio $(K)$, frisando-se que a "concentração" do sólido não toma parte deste raciocínio. Desta maneira pode-se promover um entendimento mais significativo dos fenômenos envolvidos nos equilíbrios heterogêneos, além de se evitar possíveis erros devido a uma aplicação mecânica do princípio de Le Chatelier (QUÍLEZ-PARDO, 1997b).

\subsection{Quais são as alternativas ao princípio de Le Chatelier?}

A última questão analisada foi a de se o livro apresenta outros métodos para se prever a evolução de um sistema em equilíbrio químico além da aplicação literal do princípio de Le Chatelier. Cinco livros apresentam o uso da constante de equilîbrio (Kc ou Kp) para prever alterações de equilíbrios químicos (US, VN, GEPEQ, TC e RF). Dois destes mostram o uso da constante de equilíbrio de maneira superficial. O primeiro deles (US) discute o uso da constante de equilíbrio em uma "observação", destacada a seguir: "outra maneira de entendermos o deslocamento desse equilîbrio seria por meio de uma análise da exp ressão do $\mathrm{K}_{\mathrm{c}}$." (US, p.369). E o segundo (VN) diz textualmente que: "a oposição à ação externa pode ser verificada pela expressão da constante de equilíbrio." (VN, p.398).

Após esta afirmação, a autora cita um exemplo genérico em que o aumento da quantidade de reagentes significa aumentar o denominador e que para que $\mathrm{K}$ permaneça constante deve-se diminuir a quantidade de produtos.

Os outros três livros (RF, TC, GEPEQ) discutem mais detalhadamente a utilização da constante de equilíbrio. O livro RF utiliza a constante apenas para estudar o efeito da variação de concentração no equilíbrio. É definido o conceito de quociente de reação $\left(Q_{c}\right)$ e são comparados se estes valores são iguais ou diferentes ao valor de $K$ para concluir se o sistema está ou não em equilíbrio. Uma estratégia semelhante é utilizada pelo livro TC, porém este mostra os valores de $\mathrm{K}$ para alterações de pressão além das mudanças nas concentrações. $O$ uso da 
constante é apresentado também em variações de temperatura por meio de exemplos empíricos em tabelas. O livro GEPEQ discute a manutenção dos valores de $K$ quando se altera a concentração ou pressão através de exercícios em que o aluno calcula o valor de $Q_{c}$ após a adição de um dos constituintes do sistema ou após uma variação de pressão, e o compara com o valor de $K_{c}$ na temperatura fornecida. Além destes fatores, a alteração da temperatura é relacionada com a mudança da constante através de exemplos empíricos em forma de tabelas. 


\section{CONCLUSÕES}

Neste trabalho foram apresentados e discutidos vários aspectos importantes na abordagem do tema equilíbrio químico. O primeiro deles é que o princípio de Le Chatelier é a ferramenta, quase que exclusiva, para prever possíveis alterações em sistemas em equilíbrio químico. Do ponto de vista histórico, foram encontrados alguns aspectos que contribuem para este "status" do princípio de Le Chatelier como, por exemplo, o de constituir o princípio um enunciado relativamente simples e a crença de que o mesmo tem um caráter universal e infalível. Isto proporcionando uma grande popularidade ao princípio no ensino de química até os dias atuais, embora tenha acarretado uma série de consequências indesejáveis ao entendimento da completa e correta natureza do tema.

Dentre as diversas formulações que Le Chatelier propôs em seus trabalhos, aquela que está largamente presente nos livros didáticos analisados é semelhante à formulação apresentada por Ostwald em 1904 que, por sua vez, é baseada no enunciado mais simples e geral do próprio Le Chatelier. Outro aspecto importante foi observar que todas as explicações e análises específicas que Le Chatelier apresentou em seus trabalhos sobre mudanças de temperatura, força eletromotriz, pressão e concentração foram eliminadas, perpetuando-se ao longo dos anos, nos textos didáticos, somente o enunciado mais geral, desacompanhado de suas explicações e ilustrações. Também vale lembrar que é esta formulação que foi principalmente sujeita a críticas desde o seu início e finalmente foi corrigida pelo próprio autor anos mais tarde. Uma das críticas mais contundentes diz respeito ao uso indiscriminado do princípio em situações em que ele não pode ser aplicado. Nestes casos, um rigoroso controle de variáveis e uma análise criteriosa são necessários para que o princípio possa ser aplicado.

Além desta reflexão sobre a história da proposição do princípio, este estudo procurou verificar como o mesmo é abordado em livros didáticos do nível médio, e também como são discutidas determinadas características referentes às alterações de equilibrios químicos presentes nestes livros. Foi, assim, analisado como os livros didáticos abordam as variáveis: concentração, temperatura, catalisador e pressão, quando estas provocam alterações no estado de equilibrio. A concentração é a variável mais presente, mas, em muitos casos, os textos dos livros podem gerar confusões entre massa e concentração da substância. Em relação à temperatura, 
verificou-se que poucos são os livros que realmente se preocupam em enfatizar que a constante de equilibrio muda com a alteração da mesma, conceito este fundamental para que o aluno compreenda como esta variável se comporta em reações endotérmicas e exotérmicas. A variável pressão é lembrada pela maioria dos livros, porém o "modelo pistão" é o preferido de todos, podendo ocasionar obstáculos para que o aluno faça a transposição para problemas do cotidiano. Este modelo não reflete, por exemplo, o que ocorre em um reator fechado do processo de produção de amônia, equilíbrio mais explorado no "modelo pistão". E finalmente o efeito do catalisador passa discretamente em alguns livros, e muitos autores apenas apresentam o fato de que um catalisador não afeta o equilíbrio químico, ou seja, não explicam a razão disto.

A análise das ilustrações em livros didáticos de química no nível médio, que abordam as alterações dos sistemas em equilíbrio químico, permitiu verificar dois aspectos importantes. O primeiro diz respeito à predominância de figuras macroscópicas e de gráficos, $85 \%$ do total, comparando-se com as ilustrações que abordam o nível molecular. Nesta maioria, a mudança da variável concentração é a preferida nas discussões sobre as alterações dos sistemas em equilibrio (36\% do total das figuras). Neste grupo, destacaram-se duas ilustrações: a primeira refere-se ao gráfico presente na figura 4 , que deixa claro ao aluno como a alteração da concentração do sistema em equilíbrio se comporta com o decorrer do tempo até resultar em um novo estado de equilibrio. O segundo destaque refere-se ao exemplo do equilibrio $\mathrm{N}_{2} \mathrm{O}_{4(\mathrm{~g})} \rightleftarrows 2 \mathrm{NO}_{2(\mathrm{~g})}$, presente em $53 \%$ das figuras macroscópicas que, por meio de aspectos de coloração, permitem a visualização da modificação do sistema e a verificação da coexistência de reagentes e produtos no equilíbrio químico. O nível que gera maior dificuldade aos estudantes, o microscópico, é aquele que apresenta o menor número de figuras explicativas para se compreender as alterações de equilíbrios químicos. Neste caso, faz-se importante a presença do professor para que os alunos criem seus modelos de partículas e, em seguida, discuta com eles os modelos reconhecidos do ponto de vista científico.

$O$ segundo aspecto fundamental diz respeito à relação de todas as figuras analisadas com os três níveis propostos pelo triângulo de Johnstone. Apenas três ilustrações, 9\% do total, apresentavam a alteração do sistema em equilíbrio relacionado aos três vértices do triângulo, apesar da simultaneidade verificada para os níveis macro e microscópico (figura 10). 
A alternativa para se evitar os possíveis problemas já apontados para estas figuras seria a separação destes níveis em duas ilustrações distintas, uma para cada nível. Percebem-se, no restante das ilustrações, dois casos típicos: a apresentação de uma figura macroscópica associada ao respectivo nível simbólico (maioria dos exemplos) ou a visualização de uma figura microscópica seguida de seu nível representacional. Uma alternativa interessante para interligar completamente os três níveis do triângulo de Johnstone seria a complementação do nível microscópico na figura 4, pois esta importante análise gráfica e suas devidas explicações já estão associadas ao nível simbólico e a outra figura macroscópica.

Por fim, procurou-se abordar quais as alternativas ao uso do princípio de Le Chatelier e encontrou-se como única alternativa o uso da constante de equilíbrio, solução já apontada pela literatura. Porém, menos da metade dos livros (3) fez uma discussão mais enfática sobre esta alternativa.

Este trabalho mostrou como os autores de livros de Química para o Ensino Médio apresentam o conceito do Princípio de Le Chatelier, marcado de caráter indutivo, vago, ambíguo, universal, sem fundamentação teórica. Em geral, não são discutidos exemplos que mostrem as suas limitações, ou casos onde a aplicação literal e linear do princípio pode levar a predições incorretas. Também não há, em geral, um controle rigoroso nas variáveis envolvidas, principalmente no que diz respeito a equilîbrios em sistemas gasosos. Assim, foi claramente observado que uma das características mais frequentes dos livros escolares é a limitação em apresentar enunciados declarativos de conceitos químicos sem mostrar seus limites de validação. Tudo isto pode transmitir ao aluno a ideia de que se trata de um princípio infalível ou uma verdade absoluta. Pode levar ao aluno a ideia errada que a evolução de um sistema em equilíbrio ou até mesmo o estado de equilíbrio em si é regido por um princípio que traduzira uma relação fundamental da natureza ao invés de ter a clara percepção de que se trata de uma generalização a partir de observações empíricas que deve ser utilizada de maneira criteriosa.

Esse tratamento superficial do Princípio de Le Chatelier como uma regra simples, universal e de caráter algorítmico favorece processos de ensinoaprendizagem baseados na memorização, repetição e na utilização mecânica (não significativa) do princípio sem compreensão dos conceitos envolvidos. O fato de não se provocar pensamentos contraditórios e uma discussão criteriosa pode ocasionar dificuldades e erros conceituais dos diversos conceitos químicos pelos estudantes. 
É possível questionar se as dificuldades relacionadas à resolução de problemas que se tem apontado na literatura, tais como a falta de reflexão prévia e um tratamento superficial do problema que leva a um operativismo mecânico, dificuldades quanto ao controle de variáveis e incapacidade em distinguir entre as informações essenciais e irrelevantes para resolver um problema (QUÍLEZ-PARDO, 1993), não tenham relação direta com a ilusão provocada por simplificações de fácil memorização e operação como as simples "regrinhas" derivadas do Princípio de Le Chatelier. Ainda mais, se a aplicação direta das mesmas em exercícios e problemas de caráter qualitativo for colocada como um dos principais objetivos educacionais.

Nos dias de hoje, compreender química significa compreender a natureza molecular e dinâmica da matéria e, ainda, ser capaz de operar neste nível abstrato ao se fazer previsões do comportamento da mesma. Desta forma, a proposta apresentada por Johnstone (1994) dos níveis de compreensão da química se constitui em uma importante concepção do processo de ensino-aprendizado desta Ciência. No tema estudado, a interligação dos três níveis do triângulo de Johnstone para uma mesma ilustração, com discussões deste aspecto no texto, pode ser fundamental para mostrar o real entendimento dos conceitos químicos envolvidos nas alterações de uma variável do sistema em equilibrio químico. Assim, ao se deparar com uma ilustração que não aborde um determinado nível do triângulo, professores e autores de materiais didáticos podem propor exercícios aos estudantes para que representem o nível faltante na ilustração em questão, com o objetivo de que o mesmo exemplo contemple todos os vértices propostos no triângulo de Johnstone.

Cabe aqui ressaltar que o princípio de Le Chatelier funciona, na maioria dos casos, como uma regra qualitativa para predizer como um equilíbrio reage a uma determinada alteração de uma variável do sistema. O grande problema, portanto, está na constatação dos problemas, aqui largamente apontados, que o seu uso exclusivo provoca quando se trata de estudar a evolução de sistemas em equilíbrio. É preciso, portanto, que os professores de todos os níveis de ensino de química, tenham claro as limitações do uso do princípio de Le Chatelier e os problemas que o uso exclusivo do mesmo pode provocar no correto entendimento da natureza dinâmica do equilibrio químico, constituindo-se em um verdadeiro obstáculo epistemológico (QUíLEZ-PARDO, 1997a). 
Ao abordar a predição das alterações que pode sofrer um sistema em equilibrio, é preciso considerar todos os fatores que afetam o sistema de uma maneira mais rigorosa fazendo, principalmente, um uso mais extensivo da equação da constante de equilíbrio na resolução de problemas desta natureza. Assim, o princípio de Le Chatelier poderia ser colocado em seu devido lugar, uma regra qualitativa prática e de valor preditivo limitado, e se evitaria assim, a redução do fenômeno equilíbrio químico à mera aplicação deste princípio.

Todos estes aspectos devem ser levados em consideração por professores de química e autores de livros didáticos para que, independentemente da metodologia escolhida: princípio de Le Chatelier com critérios bem definidos e/ou o uso da constante de equilibrio, se promova o real entendimento dos conceitos químicos envolvidos com as alterações impostas a um sistema em equilibrio químico. 


\section{REFERÊNCIAS BIBLIOGRÁFICAS}

ALLSOP, R. T. e GEORGE, N. H. Le Chatelier - a redundant principle? Education in Chemistry, v. 21, p. $54-56,1984$.

BARKER, V., Beyond appearances: students' misconceptions about basic chemical ideas, A report prepeared for the Royal Society of Chemistry, 2nd edition, 2001. (http://www.rsc.org/education/teachers/learnnet/pdf/LearnNet/rsc/miscon.pdfacessado em 12/09/2008).

BRASIL, Secretaria de Educação Média e Tecnológica, Ministério da Educação e Cultura, Parâmetros Curriculares Nacionais - Ensino Médio: Ciências da Natureza, Matemática e suas tecnologias. Brasília: MEC/Semtec, v. 3, 1999.

BRASIL, Secretaria de Educação Média e Tecnológica, Ministério da Educação e Cultura, PCN+- Ensino Médio: Orientações educacionais complementares aos Parâmetros Curriculares Nacionais - Ciências da Natureza, Matemática e suas tecnologias. Brasília: MEC/Semtec, 2002. p. 99.

CAMACHO, M. e GOOD, R. Problem solving and chemical equilibrium, Journal of Research in Science Teaching, v. 26, p. 251-272, 1989.

CHEUNG, D. The scientific inadequacy of Le Chatelier's principle. Hong Kong Science Teachers Journal, v. 22, p. 35-43, 2004.

(http://www3.fed.cuhk.edu.hk/chemistry, acessado em 15/03/2009).

CHEUNG, D. The adverse effects of Le Chatelier's principle on teacher understanding of chemical equilibrium. Journal of Chemical Education, v. 86, p. 514$518,2009$.

DE HEER, J. The Principle of Le Chatelier and Braun. Journal of Chemical Education, v. 34, p. 375-380, 1957. 
FRACALANZA, H. N; HOFLING, M. E.; LEÃO, F. B. F.; AMARAL, A. I.; AMORIM, R. C. A. e SERRÃO, M. S. O livro Didático de Ciências no Brasil, editora Komedi, 2006.

GOLD, J. e GOLD, V. Neither Le Chatelier's nor a principle? Chemistry in Britain, p. 802-804, 1984.

JOHNSTONE, A. H. Teaching of chemistry: logical or psychological? Chemistry Education: Research and Practice in Europe, vol. 1, n. 1, 2000.

JOHNSTONE, A. H. The Development of Chemistry Teaching, The Forum, v. 70, n. 9, 1993.

JOHNSTONE, A. H. The Future Chape of Chemistry Education, Chemistry Education: Research and Practice, vol. 5, $\mathrm{n}^{\circ}$ 3, 2004.

KATZ, L. A systematic way to avoid Le Chatelier's principle in chemical reaction. Journal of Chemical Education, v. 38, p. 375-377, 1961.

KEMP, H. R., The effect of Temperature and pressure on Equilibria: a derivation of the van't Hoff rules, Journal of Chemical Education, v. 64, p. 482-484, 1987.

LACY, J. E. Equilibria that shift left upon addition on more reactant. Journal of Chemical Education, v. 82, p. 1192-1193, 2005.

LE CHATELIER, H. L. Sur un énoncé general des lois des équilibres chemiques. Comptes Rendus, v. 99, p. 786-789, 1884.

LE CHATELIER, H. L. Leçons sur le carbone et lois chimique, Nuovelle édition, Paris: Librairie Scientifique J. Hermann, 1926.

LEVINE, I.N. Physical Chemistry. New York: McGraw-Hill Book Co., 1988, p. 186. 
MARTORANO, S. A. A. As concepções de ciência dos livros didáticos de química, dirigidos ao ensino de química, no tratamento da cinética química no período de 1929 à 2004. Dissertação de Mestrado, IQ - USP, 2007.

MASKILL, R. e CACHAPUZ, A. F. C. Learning about chemistry topic of equilibrium, the use of word association tests to detect development conceptualizations. International Journal of Science Education, v. 11, p. 57-59, 1989.

MILAGRES, O. S. V., JUSTI, S. R., Modelos de Ensino de Equilíbrio Químicoalgumas considerações sobre o que tem sido apresentado em livros didáticos no ensino médio, Química Nova na Escola, n. 13, 2001.

OESPER, R. E., The Scientific Career of Henry Louis Le Chetelier. Journal of Chemical Education, v. 8, n. 3, p. 442 - 461, 1931.

PEREIRA, M. P. B. A. Equilibrio Químico - dificuldades de aprendizagem. Química Nova, v. 12, n. 1, p. 76-81, 1989.

QUÍlEZ-PARDO, J.; SOLAZ-PORTOLES, J. J.; CASTELLÓ-HERNABDEZ, M. e SANJOSÉ-LOPEZ, V. La necesidad de un cambio metodológico en la enseñanza Del equilibrio químico: Limitaciones del principio de Le Chatelier. Ensenãnza de Las Ciencias, v. 11, p. 281-288, 1993.

QUÍLEZ-PARDO, J. e SANJOSÉ-LOPEZ, V. Errores conceptuales en el estudio Del equilibrio químico: Nuevas aportaciones relacionadas com la incorreta aplicación Del principio de Le Chatelier. Ensenãnza de Las Ciencias, v. 12, p. 123-133, 1995.

QUÍLEZ-PARDO, J. Una formulación para un princípio: analisis histórico del principio de Le Chatelier. Revista Mexicana de Fisica, v. 41, p. 586-598, 1995.

QUÍLEZ-PARDO, J. e SOLAZ-PORTOLES, J. J. Students and teachers misapplication of the Le Chateliers principle. Implications for the teaching of chemical equilibrium. Journal of Research in Science Teaching, v. 33, p. 939-957, 1995a. 
QUÍLEZ-PARDO, J. E. e SOLAZ-PORTOLES, J. J. Evolución histórica del principio de Le Chatelier. Caderno Catarinense de Ensino de Física, v. 12, p. 123-133, 1995b.

QUÍLEZ-PARDO, J. e SOLAZ-PORTOLES, J. J. Una formulación sencilla, cuantitativa y precisa para el principio de Le Chatelier". Educación Química, v. 7, p. 202-208, 1996a.

QUÍLEZ-PARDO, J. e SANJOSÉ-LOPEZ, V. El principio de Le Chatelier através de la história y su formulación didáctica em la enseñanza del equilíbrio químico. Ensenãnza de Las Ciencias, v. 14(3), p. 381-390, 1996b.

QUÍLEZ-PARDO, J. El principio de Le Chatelier como regla cualitativa: um obstáculo epistemológico en el aprendizaje del equilibrio químico. Infancia y Aprendizaje, v. 78, p. 73-86, 1997a.

QUÍLEZ-PARDO, J. Superación de errores conceptuales del equilibrio químico mediante una metodología basada en el empleo exclusivo de la constante de equilibrio. Educación Química, v. 8, p. 73-86, 1997b.

QUÍLEZ-PARDO, J. Persistencia de errores conceptuales relacionados con La incorreta aplicación del principio de Le Chatelier. Educación Química, v. 9, p. 367$377,1998$.

RAVIOLO, A. e GARRITZ, A. Analogias no Ensino de Equilíbrio Químico, Química Nova na Escola, n. 27, p. 13-25, 2008.

RAVIOLO, A. e MARTÍNEZ-AZNAR, M. Uma revisión sobre las concepciones alternativas de los estudiantes em la relación con el equilibrio químico. Clasificación y síntesis de sugerencias didáticas, Educación Química, v. 13, p. 159-165, 2003.

SKOOG, D. A.; WEST, D. M.; HOLLER, F.J e CROUCH, S.R. Fundamentos de Química Analítica. São Paulo: Pioneira Thomson Learning, 2006. p.225 e 253. 
SOLAZ-PORTOLES, J. J. e QUÍLEZ-PARDO, J. Changes of extent of reaction in open chemical equilibria, Chemistry Education: Research and Practice in Europe, v. 2, p. 338-340, 2001.

TORRES, E. M. Effect of a perturbation on the chemical equilibrium: comparison with Le Chatelier's Principle, Journal of Chemical Education, v. 84, p. 516-519, 2007.

TREPTOW, R. S. Le Chatelier's Principle, A reexamination and method of graphic illustration. Journal of Chemical Education, v. 57, p. 417-553, 1980.

TYSON, L.; TREAGUST, D. F. e BUCAT, R. B. The complexity of teaching and Learning Chemical Equilibrium. Journal of Chemical Education, v. 76, p. 554-558, 1999.

VOSKA, K. W. e HEIKKINEN, H. W. Identification and analysis of student conceptions used to solve chemical equilibrium problems. Journal of Research in Science Teaching, v. 32, p. 160-176, 2000.

WILSON, A. H. Equilibrium: A teaching/learning activity. Journal of Chemical Education, v. 75, p. 1176-1177, 1998. 


\section{APÊNDICE}

Apêndice A: Questões para análise do princípio de Le Chatelier em livros didáticos.

LIVRO:

SIGLA:

1) O PLC é apresentado de início? dedutivo?)

Se sim, cada alteração de equilibrio é justificada pelo princípio? (método

2) O PLC é apresentado após a apresentação das discussões sobre alteração do equilibrio químico, como uma generalização? (método indutivo?)

Se sim, é utilizado para justificar as alterações antes observadas?

3) Qual o 'status' do PLC?

a) generalização útil? diz isto textualmente?

b) lei científica? diz isto textualmente?

c) hipótese? diz isto textualmente?

4) Afirma que o deslocamento do equilibrio é governado (ou definido) pelo PLC? Qual o termo utilizado?

\begin{tabular}{|c|c|c|c|c|c|c|}
\hline & \multicolumn{3}{|c|}{ alteração de } & \multirow[b]{2}{*}{$\begin{array}{l}\text { adição de } \\
\text { catalisador }\end{array}$} & \multirow[b]{2}{*}{$\begin{array}{c}\text { equilíbrio } \\
\text { heterogêneo }\end{array}$} & \multirow{2}{*}{$\begin{array}{l}\text { outro } \\
\text { caso } \\
\text { Qual? }\end{array}$} \\
\hline & [ ] & $\mathrm{P}$ & $T$ & & & \\
\hline $\begin{array}{l}\text { 5) Usa exemplos genéricos do } \\
\text { tipo } A+B \rightarrow C+D \text { ? Quantos? } \\
\text { (representacional) }\end{array}$ & & & & & & \\
\hline $\begin{array}{lrr}6) \quad \text { Usa } & \text { exemplos } & \text { reais } \\
\text { mostrando } & \text { as } & \text { equações } \\
\text { químicas? } & & \text { Quantos? } \\
\text { (representacional) } & \end{array}$ & & & & & & \\
\hline $\begin{array}{l}\text { 7) Usa a equação de } \mathrm{K} \text { (ou o } \\
\text { quociente de reação Q) para } \\
\text { prever o que acontece quando } \\
\text { um equilíbrio é perturbado, ou } \\
\text { seja, para prever o } \\
\text { deslocamento do equilibrio? } \\
\text { (representacional/ matemático) }\end{array}$ & & & & & & \\
\hline $\begin{array}{l}\text { 8) Apresenta gráfico de } \\
\text { concentração x tempo quando } \\
\text { discute (representacional) }\end{array}$ & & & & & & \\
\hline $\begin{array}{l}\text { 9) Apresenta figuras ilustrativas } \\
\text { com representação } \\
\text { microscópica (moléculas) } \\
\text { (representacional/ microscópico) }\end{array}$ & & & & & & \\
\hline $\begin{array}{l}\text { 10) Apresenta fotos ou } \\
\text { desenhos de sistemas reais } \\
\text { (representacional/ } \\
\text { macroscópico) }\end{array}$ & & & & & & \\
\hline
\end{tabular}


11) Sobre variação de pressão:

a) Usa o modelo do pistão?

b) Trata da adição de um gás participante do equilibrio? Volume constante ou não?

c) Trata da adição de um gás inerte? Volume constante ou não?

d) Trata de algum caso onde o volume é constante?

12) Sobre variação de temperatura:

a) Afirma no texto que $\mathrm{K}$ só varia com a temperatura?

b) Mostra como $\mathrm{K}$ varia com a temperatura nos casos de rações exo e endotérmicas?

i. mostra com gráfico

ii. mostra com tabela

13) Sobre variação a adição de catalisador:

Afirma textualmente que um catalisador não altera o equilíbrio só aumenta as velocidades de reações diretas e inversas?

i. ilustra o fato com um gráfico de energia de ativação?

ii. ilustra o fato com um gráfico de concentração $x$ tempo?

14) Sobre equilibrios heterogêneos:

Afirma que o PLC não vale neste caso? Ou algo semelhante?

Diz textualmente que a adição/remoção de sólido não altera o equilíbrio? Como justifica o fato anterior?

15) Fala sobre o que acontece com a velocidade das reações quando se perturba um equilíbrio? Como isto é mostrado (gráficos, textos, figuras...)?

16) Usa algum modelo explicativo para justificar a alteração do equilibrio? Qual? (teoria das colisões moleculares, lei da ação das massas...) 